\title{
Simulation Study of the Formation of Corrosive Gases in Coal Combustion in an Entrained Flow Reactor
}

\author{
Maximilian von Bohnstein, Coskun Yildiz *, Lorenz Frigge, Jochen Ströhle and Bernd Epple
}

Institute for Energy Systems and Technology, Technische Universitat Darmstadt, 64289 Darmstadt, Germany; maximilian.vonbohnstein@est.tu-darmstadt.de (M.v.B.); lorenz.frigge@est.tu-darmstadt.de (L.F.); jochen.stroehle@est.tu-darmstadt.de (J.S.); bernd.epple@est.tu-darmstadt.de (B.E.)

* Correspondence: coskun.yildiz@est.tu-darmstadt.de

Received: 20 July 2020; Accepted: 24 August 2020; Published: 1 September 2020

\begin{abstract}
Gaseous sulfur species play a major role in high temperature corrosion of pulverized coal fired furnaces. The prediction of sulfur species concentrations by 3D-Computational Fluid Dynamics (CFD) simulation allows the identification of furnace wall regions that are exposed to corrosive gases, so that countermeasures against corrosion can be applied. In the present work, a model for the release of sulfur and chlorine species during coal combustion is presented. The model is based on the mineral matter transformation of sulfur and chlorine bearing minerals under coal combustion conditions. The model is appended to a detailed reaction mechanism for gaseous sulfur and chlorine species and hydrocarbon related reactions, as well as a global three-step mechanism for coal devolatilization, char combustion, and char gasification. Experiments in an entrained flow were carried out to validate the developed model. Three-dimensional numerical simulations of an entrained flow reactor were performed by CFD using the developed model. Calculated concentrations of $\mathrm{SO}_{2}, \mathrm{H}_{2} \mathrm{~S}, \mathrm{COS}$, and $\mathrm{HCl}$ showed good agreement with the measurements. Hence, the developed model can be regarded as a reliable method for the prediction of corrosive sulfur and chlorine species in coal fired furnaces. Further improvement is needed in the prediction of some minor trace species.
\end{abstract}

Keywords: Computational Fluid Dynamics (CFD); high temperature corrosion; pulverized fuel-firing systems

\section{Introduction}

Coal is one of the most abundant energy sources and accounts for up to one-third of the world's primary energy consumption in 2018 [1], and forecasts see only a slight decrease in coal consumption over the next twenty years [2]. During the last few decades, major efforts have been made to minimize pollutant emissions from coal-fired power plants. Air staging as a primary measure to reduce $\mathrm{NO}_{\mathrm{x}}$ emissions is generally applied in furnaces. However, the reducing conditions prevailing in the air staging area cause the formation of corrosive sulfur species, such as $\mathrm{H}_{2} \mathrm{~S}$ and COS, which can lead to high-temperature corrosion on the furnace walls [3,4].

Despite their importance, the reaction kinetics causing the formation of these sulfur species are still not fully understood. The complex kinetics, which comprise a large number of species and different kinds of elementary reactions, are difficult to determine experimentally. To describe the sulfur reactions in detail, elaborate reaction mechanisms are necessary, which are not applicable to be linked to Computational Fluid Dynamics (CFD) Simulations. However, the computing time of CFD simulations with several million grid cells becomes manageable when reduced reaction mechanisms are used. The mechanism has to be chosen carefully regarding the operation conditions of the investigated facility. 
The procedure of combining experiments in a drop tube furnace and CFD simulations is often used to gain information about combustion processes, develop and validate reaction models, or investigate pollutant formation [5-9]. One can find many studies on simulation of $\mathrm{NO}_{\mathbf{x}}$ emissions in the literature. Han et al. [10] implemented a skeletal mechanism into a CFD code and carried out simulations of an entrained flow reactor to predict $\mathrm{NO}_{\mathrm{x}}$ emissions. Wei et al. [11] added sulfur chemistry to the reaction mechanism. They predicted $\mathrm{CO}, \mathrm{NO}_{\mathrm{x}}$, and $\mathrm{SO}_{\mathrm{x}}$ concentration profiles in the entrained flow reactor by CFD simulations. Lee et al. [12] investigated in a drop tube furnace the influence of coal volatile matter content on fuel NO emissions. They performed CFD simulations with a simple reaction model and obtained a good agreement between measurements and calculations. Other studies focus on the prediction of $\mathrm{SO}_{x}$ emissions with simplified models and mechanisms $[13,14]$. Müller et al. [15] include several release mechanisms for sulfur in their simulation, but, for gas phase chemistry, only global reactions were used. This method shows good results for $\mathrm{SO}_{\mathrm{x}}$ emission prediction. However, the formation of intermediate species, like COS, is not possible. Maffei et al. [16] developed a comprehensive model of sulfur release from coal. It includes 15 species and 15 reactions and was validated against literature data. But they performed only OD calculations and no CFD simulations.

There are few studies regarding prediction of corrosive atmospheres by numerical simulation. Modlinski and Hardy [17] implemented four global reaction mechanisms into a CFD code to predict $\mathrm{O}_{2}$ and $\mathrm{CO}$ concentrations in a power plant furnace. They proposed an on-line corrosion risk monitoring system based on $\mathrm{O}_{2}$ and $\mathrm{CO}$ measurements and tried to adjust the demonstrated monitoring system based on the identification of reducing atmospheres. They do not incorporate trace species, like $\mathrm{H}_{2} \mathrm{~S}$ or COS. Most researchers investigate fly-ash deposition on furnace walls and heat exchangers. Li et al. [18] give a comprehensive overview of CFD-based prediction of fly-ash deposition in their review paper. Nevertheless, they do not consider corrosive atmospheres. Wang et al. [19] proposed a numerical method to predict the sulfuric acid dew point temperature. With this information, they assess the corrosion risk due to sulfuric acid dew point corrosion. They do not calculate any species concentrations.

In this study, a reaction model was developed that strikes a balance between accuracy and computational effort of CFD simulations with large computational grids. The model is incorporated in 3D-CFD simulations of an entrained flow reactor. In the presented work, not only are major pollutants, like $\mathrm{CO}$ and $\mathrm{SO}_{2}$, predicted by CFD simulations but also the concentrations of trace species, like COS and $\mathrm{H}_{2} \mathrm{~S}$. Based on studies in the literature [20] and previous work [21], this article postulates an extensive reaction mechanism to describe the formation of sulfur species and their reaction with other non-sulfur species, e.g., hydrocarbons, oxygen, and carbon-oxides, during coal combustion. The existing model, which comprised the gas phase mechanism, was updated to include sulfur species release during combustion. Three-dimensional numerical simulations of coal combustion in an entrained flow reactor at different stoichiometric ratios and temperatures were performed. The sulfur emissions of a U.S. high volatile $C$ bituminous coal were studied by combustion experiments in the entrained flow reactor. Four different air ratios $(0.7,0.8,0.9$, and 1.0) and three different temperatures $\left(1000{ }^{\circ} \mathrm{C}, 1150{ }^{\circ} \mathrm{C}\right.$, and $\left.1300{ }^{\circ} \mathrm{C}\right)$ were investigated. To validate the model, the simulation results are compared to measurements conducted in the entrained flow reactor.

\section{Reaction Model}

The objective of the simulation is the prediction of sulfur containing compounds' behavior during different stages of the coal combustion process by numerical modeling. The sulfur chemistry applicable during coal combustion, which forms the basis of the model, was already described in an earlier work from us [21] and was expanded to describe the release processes of sulfur in more detail. Mineral matter transformation of sulfur bearing minerals was added to the model. The modeling approach is described extensively in a previous article [22] and will be summarized in the following. 


\subsection{Reaction Mechanism of Solid State Reactions}

Depending on type, rank and grade of the coal the sulfur content ranges from $0.3 \%$ to $5.0 \%$. In addition to its elemental form, which is found only in trace amounts, sulfur in coal can occur in two different forms. Inorganic and organic sulfur are the major types, and the distribution between them strongly depends on the considered coal [23]; in some cases, up to $40 \%$ of inorganic sulfur have been found in coal. In case the sulfur atoms are bound directly in the carbon chains, it is termed organic sulfur. Various functional groups have been found in analyses, e.g., thiophenic and thiolic sulfur, aliphatic sulfides, and aromatic disulfides [16,24], accounting for a high complexity. The other major sulfur source in coal is inorganic sulfur, where the sulfur atoms occur in minerals. Pyrite comprises the majority of the inorganic sulfur in coal. Depending on the origin of the coal, the amount of sulfates can also be high. Gypsum is, among others, the main source of sulfates $[25,26]$. Hydrogen sulfide is mainly formed from organic sulfur during pyrolysis $[27,28]$, while inorganic sulfur is released during the transformation of mineral matter. Inorganic sulfur is accounted for as pyritic sulfur that occurs as pyrite and sulfates, which may occur as gypsum and other compounds. As gypsum represents the majority of the sulfates [26], no further sulfates are included in the model. The numerical costs of expanding the model by additional sulfate compounds would exceed the benefit of a more complex model. Organic bound sulfur is not further subdivided.

In this section, the mineral matter transformation reactions are characterized. Twelve reactions are included in the model, which are describing the fate of pyrite and gypsum in oxidizing and reducing conditions, as well as the evaporation of sodium chloride. The reaction mechanism is given in Table 1. The oxidation of pyrite starts at temperatures of approximately $330^{\circ} \mathrm{C}$, leading to the formation $\mathrm{SO}_{2}$ (c.f. reaction 3, Reference [29]). In inert atmosphere, meaning absence of oxygen, and at temperatures above $570{ }^{\circ} \mathrm{C}$, pyrite decomposes to pyrrhotite (c.f. reaction 1, Reference [25]), which then decomposes into iron and sulfur above $730^{\circ} \mathrm{C}$ (c.f. reaction 4). In the presence of oxygen iron is oxidized to iron oxides. During this reaction, hematite $\left(\mathrm{Fe}_{2} \mathrm{O}_{3}\right)$ or magnetite $\left(\mathrm{Fe}_{3} \mathrm{O}_{4}\right)$ can be formed as products. As the main product magnetite was found during pyrite combustion in drop tube experiments [30], so, for convenience, only magnetite is included in the model. It shall be mentioned that the oxidation of iron is not included in the model to reduce the computational effort. This particular reaction is not important for the prediction of corrosive atmospheres. In oxygen rich atmosphere, Pyrrhotite is also oxidized above $820^{\circ} \mathrm{C}$ to form sulfur dioxide and magnetite according to reaction 2 . Gypsum is decomposed in several steps. First, the gypsum is dehydrated according to reaction 5 [29], forming water and anhydrite. This dehydration can proceed already at low temperatures of $60{ }^{\circ} \mathrm{C}$. The second step starts at a temperature approximately $830^{\circ} \mathrm{C}$ with the decomposition of anhydrite to calcium oxide and sulfur trioxide, which reacts to sulfur dioxide and oxygen at high temperatures (c.f. reaction 6). Sulfur trioxide is neglected in the reaction mechanism, since the description of the reactions in high temperature areas of furnaces is the overall aim of the model. In oxygen rich areas, reaction 6 is promoted. In case of the absence of oxygen, anhydrite reacts mainly to calcium sulfide and carbon dioxide according to reaction 7 . According to reaction 9 calcium sulfide is oxidized to calcium oxide and sulfur dioxide [31]. Water vapor can, in the absence of oxygen, serve as an alternative oxidant, especially at high temperatures (c.f. reaction 10). In this case, the gaseous product is hydrogen sulfide. Sulfur dioxide was also proven in experiments as a product of reaction 10 [32]. However, this reaction pathway is neglected, since in the presence of oxygen hydrogen sulfide is anyway rapidly oxidized to sulfur dioxide [21]. The share of $\mathrm{NaCl}$ in the total chlorine content of coal is generally between $70-80 \%[33,34]$. The sodium chloride evaporates quickly during the pyrolysis of the coal and is then present in gaseous form (c.f. reaction 11). The gaseous sodium chloride can be bound again by reactions with aluminum silicates in the fly ash. The products of this reaction are nepheline and hydrogen chloride (c.f. reaction 12) [35]. 
Table 1. Reactions of mineral matter transformation.

\begin{tabular}{|c|c|c|c|}
\hline No. & Reaction & $\mathrm{E}\left[\frac{\mathrm{kJ}}{\mathrm{mol}}\right]$ & A \\
\hline 1 & $\mathrm{FeS}_{2}(s) \rightarrow \frac{1}{x} F e_{x} S(s)+\frac{2 x-1}{2 x} S_{2}$ & 92.04 & $195.91 / \mathrm{s}$ \\
\hline 2 & $F e_{x} S(s)+\frac{2 x+3}{3} O_{2} \rightarrow \frac{x}{3} F e_{3} O_{4}(s)+S_{2}$ & 92.5 & $2.1 \times 10^{-5} 1 / \mathrm{sPa}$ \\
\hline 3 & $\mathrm{FeS}_{2}(\mathrm{~s})+8 \mathrm{O}_{2} \rightarrow \mathrm{Fe}_{3} \mathrm{O}_{4}(s)+6 \mathrm{SO}_{2}$ & 87.9 & $0.0171 / \mathrm{sPa}$ \\
\hline 4 & $\mathrm{Fe}_{x} S(s) \rightarrow x \mathrm{Fe}(s)+0.5 S_{2}$ & 92.5 & $0.451 / \mathrm{s}$ \\
\hline 5 & $\mathrm{CaSO}_{4} \times 2 \mathrm{H}_{2} \mathrm{O}(\mathrm{s}) \rightarrow \mathrm{CaSO}_{4}(\mathrm{~s})+2 \mathrm{H}_{2} \mathrm{O}$ & 120 & $3.2 \times 10^{15} 1 / \mathrm{s}$ \\
\hline 6 & $\mathrm{CaSO}_{4}(\mathrm{~s}) \rightarrow \mathrm{CaO}(\mathrm{s})+\mathrm{SO}_{2}+0.5 \mathrm{O}_{2}$ & 506.2 & $5.24 \times 10^{14} 1 / \mathrm{s}$ \\
\hline 7 & $\mathrm{CaSO}_{4}(\mathrm{~s})+4 \mathrm{CO} \rightarrow \mathrm{CaS}(s)+4 \mathrm{CO}_{2}$ & 390 & $2.2 \times 10^{14} 1 / \mathrm{s}$ \\
\hline 8 & $\mathrm{CaSO}_{4}(\mathrm{~s})+4 \mathrm{CO} \rightarrow \mathrm{CaO}(\mathrm{s})+3 \mathrm{CO}_{2}+\mathrm{COS}$ & 280.5 & $1.01 \times 10^{11} 1 / \mathrm{s}$ \\
\hline 9 & $\mathrm{CaS}(\mathrm{s})+1.5 \mathrm{O}_{2} \rightarrow \mathrm{CaO}(\mathrm{s})+\mathrm{SO}_{2}$ & 357.4 & $1.04 \times 10^{11} 1 / \mathrm{s}$ \\
\hline 10 & $\mathrm{CaS}(\mathrm{s})+\mathrm{H}_{2} \mathrm{O} \rightarrow \mathrm{CaO}(\mathrm{s})+\mathrm{H}_{2} \mathrm{~S}$ & 115.4 & $481.951 / \mathrm{s}$ \\
\hline 11 & $\mathrm{NaCl}(s) \rightarrow \mathrm{NaCl}(g)$ & 239 & $8.2 \times 10^{9} 1 / \mathrm{s}$ \\
\hline 12 & $2 \mathrm{NaCl}(\mathrm{g})+\mathrm{H}_{2} \mathrm{O}+\mathrm{Al}_{2} \mathrm{O}_{3}(s) \times 2 \mathrm{SiO}_{2} \rightarrow 2 \mathrm{NaAlSiO}_{4}(\mathrm{~s})+2 \mathrm{HCl}(\mathrm{g})$ & 41.5 & $2.5 \mathrm{~kg} / \mathrm{m}^{2} \mathrm{sPa}$ \\
\hline
\end{tabular}

\subsection{Kinetics of the Solid State Reactions}

Information about individual reaction steps in solid state kinetics is difficult to obtain. In order to draw mechanistic interpretations, it is necessary to identify an suitable reaction model. One model is generally appropriate to describe a particular reaction category and provide a rate equation, but different reaction types are required for different model approaches. The reaction rates of the solid state reactions can be evaluated generally with the following kinetic equation [36]:

$$
\frac{d \alpha}{d t}=K \cdot f(\alpha)
$$

Here, $\alpha$ represents the conversion fraction, $K$ describes the rate constant and $f(\alpha)$ is the kinetic model function, which is used to describe the specific reaction process. The conversion fraction is calculated on the basis of the mass fraction and is defined as [37]:

$$
\alpha=\frac{m_{0}-m_{t}}{m_{0}-m_{\text {final }}}
$$

$m_{0}$ describes the mass at the beginning, $m_{t}$ the mass at time $t$, and $m_{\text {final }}$ the remaining mass after the reaction. In this study, a total conversion is assumed, this means $m_{\text {final }}=0$. The model function $f(\alpha)$ defines the reaction type, i.e., the physical or chemical process. Several basic functions for idealized models of solid state reactions are available in the literature [36,37]. The functions used in this study are given in Table 2. These are applicable to reactions which are controlled by only one physical process or chemical reaction. The formal kinetic nth-order model (c.f. function (1) in Table 2) is used for the heterogeneous reactions of mineral matter transformation [38]. The model order is set to 1 . For the dehydration process of gypsum, in contrast to all other reactions, the reaction of calcium sulfide with oxygen (c.f. reaction 8) is described using a Jander equation (c.f. function (3)) as a mechanism function [31]. The authors obtained the best results for the reaction of CaS with Oxygen with this mechanism function. The evaporation of $\mathrm{NaCl}$ is modeled with an Arrhenius approach. The kinetic parameters are listed in Table 1 . The secondary binding of $\mathrm{NaCl}$ into the fly ash is modeled as a function of the particle surface $A_{p}$ and the mass of Metakaolinite $m_{k a 0}$ :

$$
\frac{d m_{k a o}}{d t}=-k_{e f f} \cdot A_{p} \cdot m_{k a o}
$$


Table 2. Mechanism functions of the solid state reactions.

\begin{tabular}{cc}
\hline No. & Function \\
\hline 1 & $f(\alpha)=(1-\alpha)^{n}$ \\
2 & $f(\alpha)=2(1-\alpha)[-\ln (1-\alpha)]^{0.5}$ \\
3 & $f(\alpha)=1.5(1-\alpha)^{2 / 3}\left[1-(1-\alpha)^{1 / 3}\right]^{-1}$ \\
\hline
\end{tabular}

The reaction rate is limited on the one hand by the diffusion of $\mathrm{NaCl}$ into the particles, expressed by $k_{D}$, and on the other hand by the chemical reaction rate $k_{c h}$. Another influencing factor is the partial pressure of $\mathrm{NaCl}, p_{\mathrm{NaCl}}$. The effective reaction rate $k_{\text {eff }}$ is then obtained:

$$
k_{e f f}=\frac{k_{c h} \cdot k_{D}}{k_{c h}+k_{D}} \cdot p_{N a C l} .
$$

The diffusion rate of sodium chloride is determined according to Equation (5):

$$
k_{D}=\frac{2 M_{m e t a} \cdot D_{N a C l}}{d_{p} \cdot R \cdot T_{p}} .
$$

The diffusion coefficient of $\mathrm{NaCl} D_{\mathrm{NaCl}}$ is $1425 \times 10^{-10} \cdot T^{1,88}$ [34].

The rate constant $K$ in Equation (1), as well as $k_{\text {chem }}$ in Equation (4), is computed by an Arrhenius approach. The kinetic parameters are obtained from isothermal kinetic data, which are given in literature for every particular reaction. The parameters for each reaction are listed in Table 1.

\section{Experimental Setup}

For validation, sulfur release during coal combustion was investigated in an entrained flow reactor. Details of the reactor design are given in Figure 1.

Gas and particles were sampled in the reaction zone. The concentrations of sulfur species $\mathrm{SO}_{2}$, $\mathrm{H}_{2} \mathrm{~S}$, and COS were measured by a mass spectrometer. The coal used in this study was a U.S. high volatile $C$ bituminous coal with high sulfur content. Disulfide, sulfate, and organic sulfur make up approximately $15 \%, 16 \%$, and $69 \%$ of total sulfur, respectively, while sulfides were not present in the coal. Additional properties of the coal are given in Table 3. A detailed description of how coal characteristics (proximate and ultimate analysis and sulfur species) were obtained is given in Reference [39].

Table 3. Coal analysis in wt.-\%, dry basis.

\begin{tabular}{lcccccc}
\hline \multicolumn{3}{c}{ Proximate Analysis } & \multicolumn{4}{c}{ Ultimate Analysis } \\
\hline Ash & Volatiles & Fixed Carbon & $\mathrm{C}$ & $\mathrm{H}$ & $\mathrm{N}$ & $\mathrm{S}$ \\
9.33 & 37.3 & 53.37 & 72.91 & 4.97 & 1.25 & 3.01 \\
\hline
\end{tabular}

The main component of the entrained flow reactor is a vertical reaction zone made of ceramic with a total length of $2200 \mathrm{~mm}$ and an ID of $70 \mathrm{~mm}$. Electrical heating elements allow the adjustment of wall temperature of the reaction zone between $900{ }^{\circ} \mathrm{C}$ and $1600{ }^{\circ} \mathrm{C}$. The fuel feed to the reaction zone is located on the top and consists of an injection nozzle connected to a water-cooled lance. Coal particles are gravimetrically dispensed from a container by a screw conveyor, transported through the water-cooled injection lance using a carrier gas stream, and enter the reaction zone. A second gas stream (co-flow) is led through the preheating section of the entrained flow reactor where it is heated up to a specified temperature, usually the wall temperature of the reaction zone. The co-flow enters the reaction zone through an annual gap located on the top, thus enabling an immediate mixing with 
the cold particle-loaded carrier gas stream to achieve high heating rates of the particles. Particles and gas move downward through the reaction zone at approximately $1 \mathrm{~m} / \mathrm{s}$. The resulting product gas is sampled using a ceramic tube entering the reaction zone perpendicularly through a bore. Sixty liters per hour or 3 to $5 \%$ of total gas flow are suctioned from the reaction zone. Particles are removed from the sampling gas stream directly at the outlet of the sampling port by a fine filter made of PTFE. The sampling gas is led to the gas analysis device in flexible PTFE tubes. Filter and tubes are heated to $180{ }^{\circ} \mathrm{C}$ to prevent the condensation of water throughout the sampling line. A quadrupole mass spectrometer (InProcess Instruments GAM 200) with a mass range of 100 a.m.u. is used for gas analysis. It is calibrated to determine the concentration of 11 species in the sampling gas, including $\mathrm{SO}_{2}, \mathrm{H}_{2} \mathrm{~S}$, and COS. Product gas and remaining particles (i.e., ash) leave the reaction zone on the bottom and are quenched by water injection.

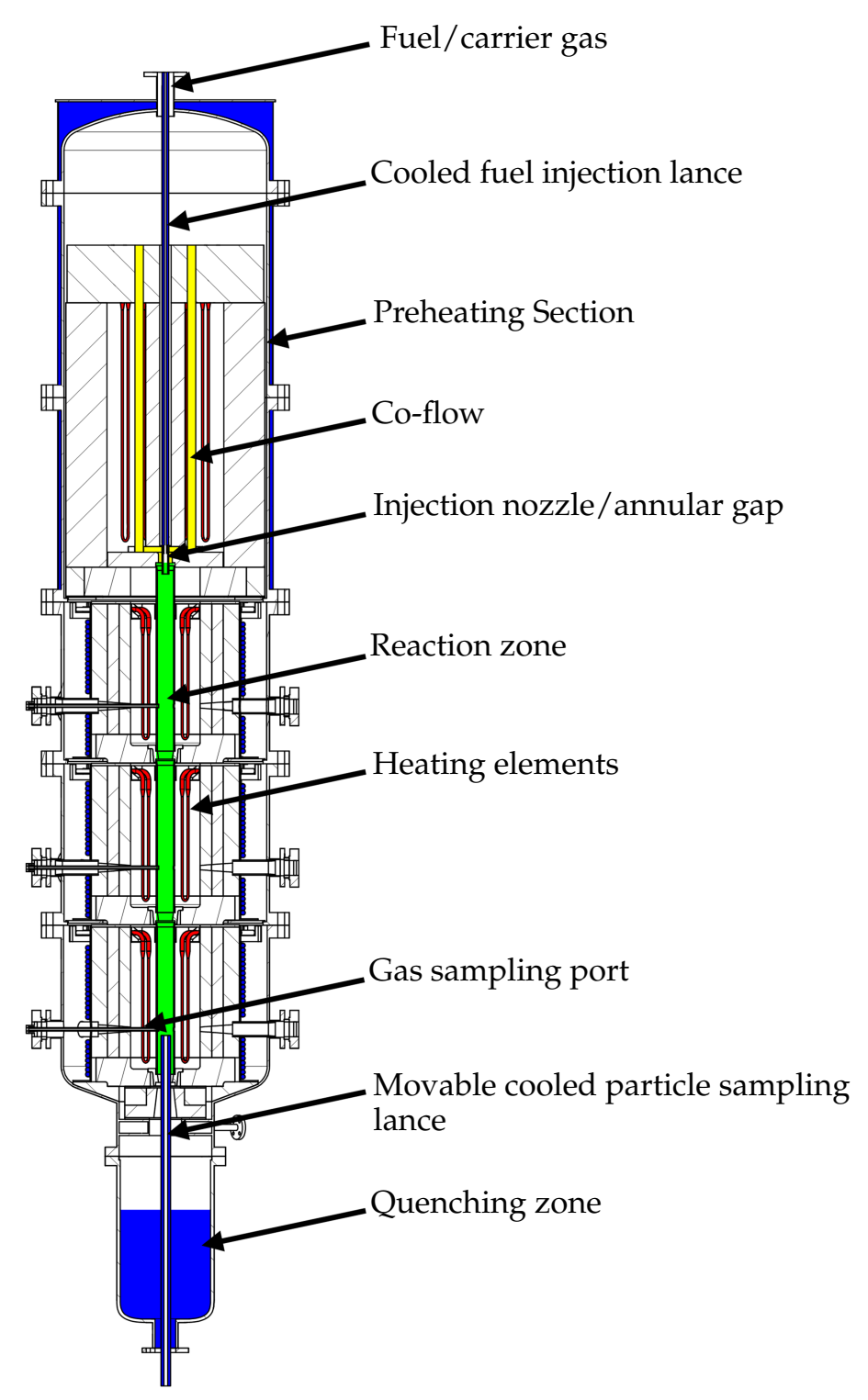

Figure 1. Entrained flow reactor.

All validation experiments were conducted following the same general scheme. The reactor was heated to the specified temperature $\left(1000{ }^{\circ} \mathrm{C}, 1150{ }^{\circ} \mathrm{C}\right.$, or $1300{ }^{\circ} \mathrm{C}$, respectively). An air flow corresponding to the desired stoichiometric ratio was introduced to the reactor and maintained by mass flow controllers. A coal mass flow of $0.2 \mathrm{~kg} / \mathrm{h}$ was then fed in the carrier gas stream. Product gas and particles were sampled at two measuring planes, $1300 \mathrm{~mm}$ and $2000 \mathrm{~mm}$ downstream of the 
injection nozzle, corresponding to residence times of approximately $1 \mathrm{~s}$ and $2 \mathrm{~s}$. When stable conditions were achieved (i.e., the concentrations measured by gas analysis reach a steady state), the operating point was maintained for approximately $20 \mathrm{~min}$, and concentrations were recorded.

\section{Numerical Setup}

The introduced model of mineral matter conversion was combined with the existing model. The model describes coal combustion and formation of sulfur species [21]. The detailed reaction mechanism of the gas phase sulfur chemistry, which is based on the sulfur mechanism of the University of Leeds [20], was updated. A reduced chemical mechanism is used to describe the C-H-O combustion system. It contains 73 elementary reactions among 17 species [40]. Reactions of chlorine species were added based on the mechanism of Pelucchi et al. [41]. The complete reaction mechanism is given in the Appendix A. It contains 48 species and 152 elementary reactions.

Numerical simulations of coal combustion in the entrained flow reactor were performed to validate the developed model. A 3D numerical grid with 505,850 computational cells was used to discretize the geometry of the reaction zone, as illustrated in Figure 2. The dimensions of the computational domain are $2200 \mathrm{~mm}$ by $70 \mathrm{~mm}$. The grid at the fuel inlet is very fine in order to reach a high spatial resolution of $0.8 \mathrm{~mm}$ in the combustion zone and to map the geometry of the injection nozzle. Towards the outlet, grid size decreases. Only the upper part of the reaction tube is shown in Figure 2 for a clearer presentation because the diameter of the tube is much smaller than the height. Reynolds-averaged transport equations are solved using the CFD simulation software FLUENT for flow, energy, and species fields. The standard $k-\epsilon$ model is used to account for turbulence. The eddy-dissipation concept [42] (EDC) allows including detailed chemical mechanisms in the simulation of turbulent flows and is therefore applied for turbulence-chemistry interaction. Radiative heat transfer is modeled with the discrete ordinates (DO) radiation model. Gas-solid interaction is considered for using the mixture model based on mixture theory. In this model solid particles are treated as a heavy gas component in the gas-solid mixture. Coal combustion is described with an enhanced version of an in-house coal combustion code, Eulerian Simulation Tool for Solid Fuels (ESTOS). This is integrated into FLUENT through user-defined functions. The standard version of ESTOS is based on a five-step global reaction scheme for coal combustion: Coal pyrolysis, char oxidation, char gasification with $\mathrm{CO}_{2}$, combustion of hydrocarbons, and $\mathrm{CO}$ oxidation and has been validated comprehensively against measurements in lab-scale furnaces and full-scale boilers [43-45]. In the extended version of ESTOS, the two global gas-phase reactions are substituted by the detailed gas-phase kinetics mentioned above. The transformation of mineral matter is included to the coal combustion and gasification model. Four particle size classes of the coal particles are included in the simulation (c.f. Table 4). A sieve analysis has been carried out and based on the results four equivalent size classes have been calculated.

Table 4. Particle size classes of coal particles.

\begin{tabular}{cccc}
\hline Size Class 1 & Size Class 2 & Size Class 3 & Size Class 4 \\
\hline $76 \mu \mathrm{m}$ & $87 \mu \mathrm{m}$ & $110 \mu \mathrm{m}$ & $167 \mu \mathrm{m}$ \\
\hline
\end{tabular}




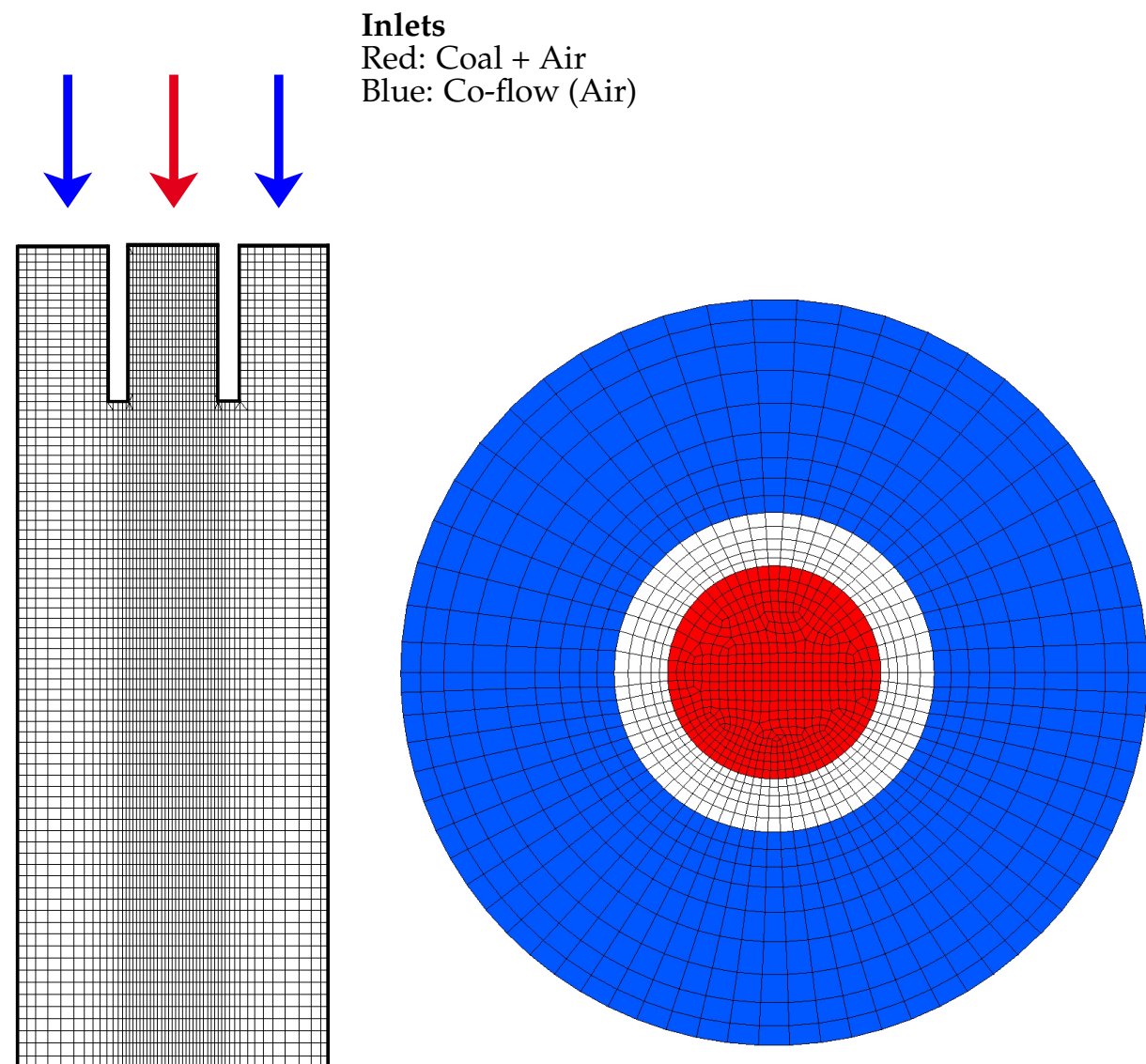

Top view

Side view (truncated)

Figure 2. Numerical mesh and inlets of the reaction tube.

\section{Results and Discussion}

Overall, twelve combinations of wall temperature and air ratio have been investigated. Three different wall temperatures $\left(1000^{\circ} \mathrm{C}, 1150^{\circ} \mathrm{C}\right.$, and $\left.1300^{\circ} \mathrm{C}\right)$ were applied, and, for each wall temperature, four air ratios from 0.7 to 1.0 were considered. Reducing conditions were created to have corrosive gases formed in the reaction tube. Gas measurements were conducted at two positions, $1300 \mathrm{~mm}$ (measuring plane 1) and $2000 \mathrm{~mm}$ (measuring plane 2) downstream of the injection nozzle. The total length of the reaction tube is $2200 \mathrm{~mm}$. So, measuring plane 1 is just after half the length of the tube, and measuring plane 2 is almost at the end of the tube. Measurements were conducted at two different residence times of the particles in the reaction tube. At measuring plane 1, the residence time is about $0.5 \mathrm{~s}$ and at measuring plane 2, the residence time is between $1 \mathrm{~s}$ and $1.5 \mathrm{~s}$, also depending on the applied boundary conditions [46]. 


\subsection{Temperature and Velocity}

The calculated 3D distributions of temperature and velocity in the upper part (0-800 $\mathrm{mm}$ axial distance) of the reaction tube for air ratio of 1.0, and three wall temperatures are shown in Figures 3 and 4 .

The coal dust and transport gas enters the reaction tube through the injection nozzle with low temperature of $20^{\circ} \mathrm{C}$. The secondary air flows through the outer annulus (c.f. co-flow in Figure 2) into the reaction tube and is preheated to the employed wall temperature.

For wall temperature of $1300{ }^{\circ} \mathrm{C}$, the highest temperature of $1800^{\circ} \mathrm{C}$ is reached in the combustion zone. The temperature level is lower for the two other cases. Downstream the combustion zone, the gas temperature reaches the wall temperature. After an axial distance of $350 \mathrm{~mm}$, the temperature remains constant, indicating that the conversion of volatiles and char is completed. At a wall temperature of $1300{ }^{\circ} \mathrm{C}$, gas temperature declines over a longer distance after the burnout zone until it matches the wall temperature. Homogeneous temperature distribution is reached on both measuring planes.
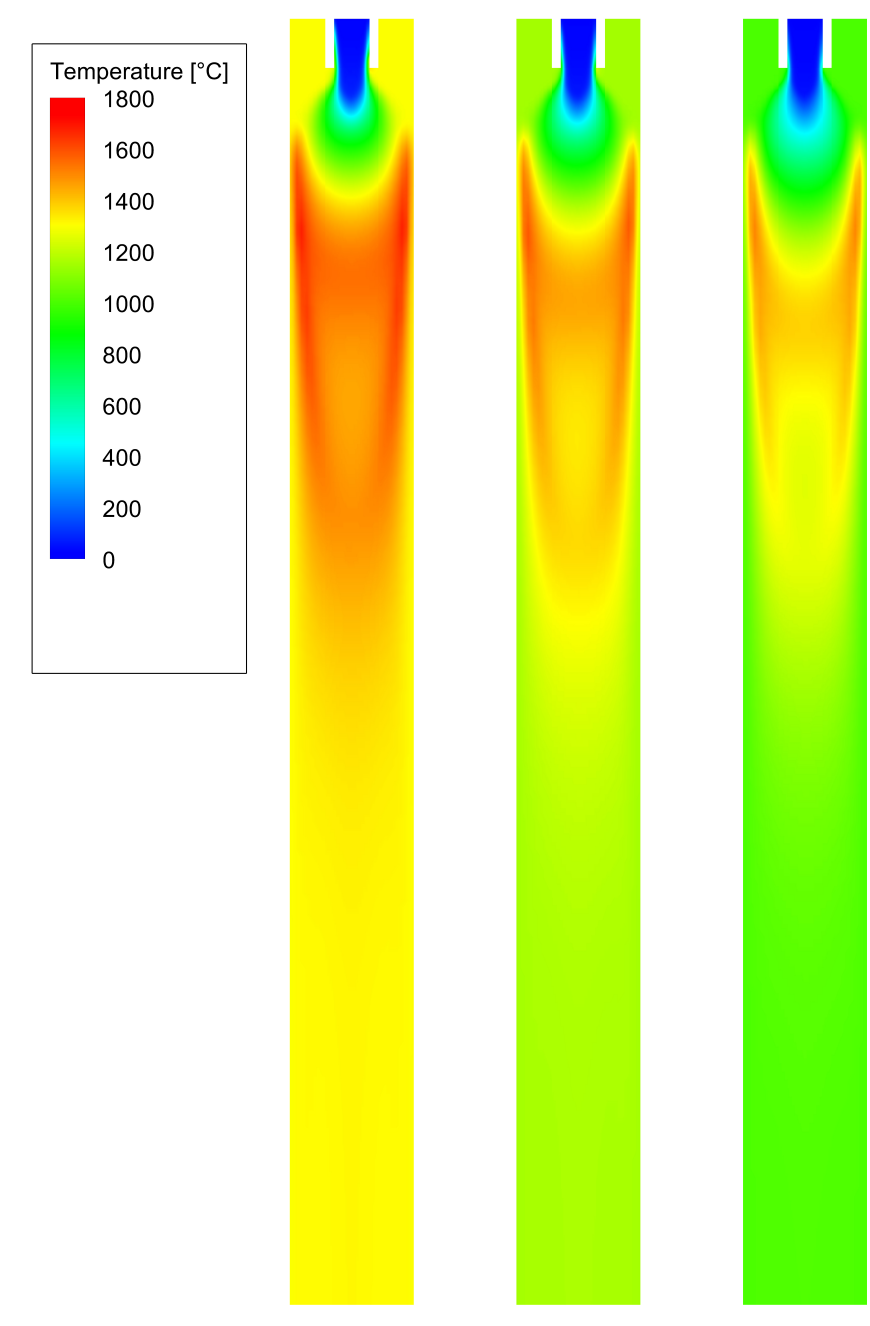

$\mathrm{T}_{\mathrm{w}}=1300^{\circ} \mathrm{C}$

$\mathrm{T}_{\mathrm{w}}=1150^{\circ} \mathrm{C}$

$T_{w}=1000^{\circ} \mathrm{C}$

Figure 3. Temperature in the first $800 \mathrm{~mm}$ of the reaction tube for the three different wall temperature cases with $\lambda=1.0$.

Figure 4 shows the axial velocity in the reaction tube for the three temperature cases at an air ratio of 1.0. There is a velocity peak at the exit of the injection nozzle in all cases. The peak value reaches $1.4 \mathrm{~m} / \mathrm{s}$ at wall temperature $1300{ }^{\circ} \mathrm{C}, 1.2 \mathrm{~m} / \mathrm{s}$ at wall temperature $1150{ }^{\circ} \mathrm{C}$, and $1.1 \mathrm{~m} / \mathrm{s}$ at wall temperature $1000{ }^{\circ} \mathrm{C}$. The co-flow velocity ranges from $0.45 \mathrm{~m} / \mathrm{s}$ to $0.35 \mathrm{~m} / \mathrm{s}$. Shortly after the 
combustion zone, a laminar flow occurs. The velocity in the middle of the tube correlates with the wall temperature. The higher the temperature, the higher is the velocity in the tube (c.f. Figure 4).

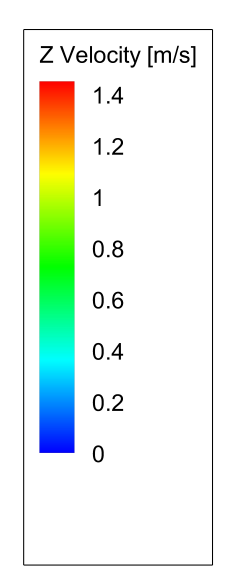

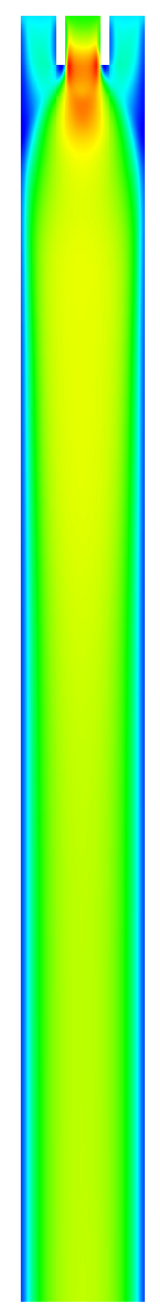

$\mathrm{T}_{\mathrm{w}}=1300^{\circ} \mathrm{C}$
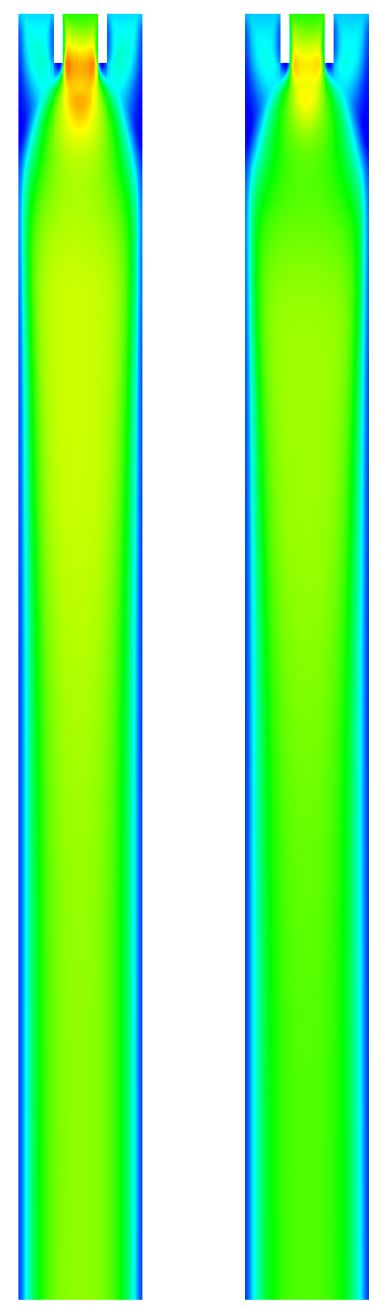

$\mathrm{T}_{\mathrm{w}}=1150^{\circ} \mathrm{C}$

$\mathrm{T}_{\mathrm{w}}=1000^{\circ} \mathrm{C}$

Figure 4. Z Velocity in the first $800 \mathrm{~mm}$ of the reaction tube for the three different temperature cases with $\lambda=1.0$.

\subsection{Main Species}

The simulation results are first evaluated with regard to the main species concentrations.

The concentrations of oxygen and carbon monoxide are shown in Figure 5 for all four air ratios at wall temperature of $1300^{\circ} \mathrm{C}$. The contour plots illustrate the oxygen concentration on the left half of the reaction tube and the carbon monoxide concentration on the right half. There are two different legends for the volume fractions at the top of the figure. Coal and air enter the reaction zone from the top through the injection lance in the middle, in which the walls are shown as a white space in the plots. Oxygen is quickly consumed by volatiles and char while $\mathrm{CO}$ is produced, leading to the temperature peak close to the inlet. There is a high CO concentration of $16 \mathrm{Vol}-\%$ in the reaction tube for air ratio 0.7 because there is not enough oxygen to oxide the $\mathrm{CO}$ to $\mathrm{CO}_{2}$. The remaining $\mathrm{CO}$ concentration is lower for the other air ratios; it amounts to $11 \mathrm{Vol}-\%$ for air ratio $0.8,5.7 \mathrm{Vol}-\%$ for air ratio 0.9 , and almost zero for air ratio of 1.0. The oxygen is rapidly consumed and the oxygen concentration reaches zero fast, although it takes slightly longer with increasing air ratio. The conditions in the reaction tube are very similar for the other wall temperatures. The combustion process is just slower, and the peak temperatures are lower, as it can be seen in Figure 3. 

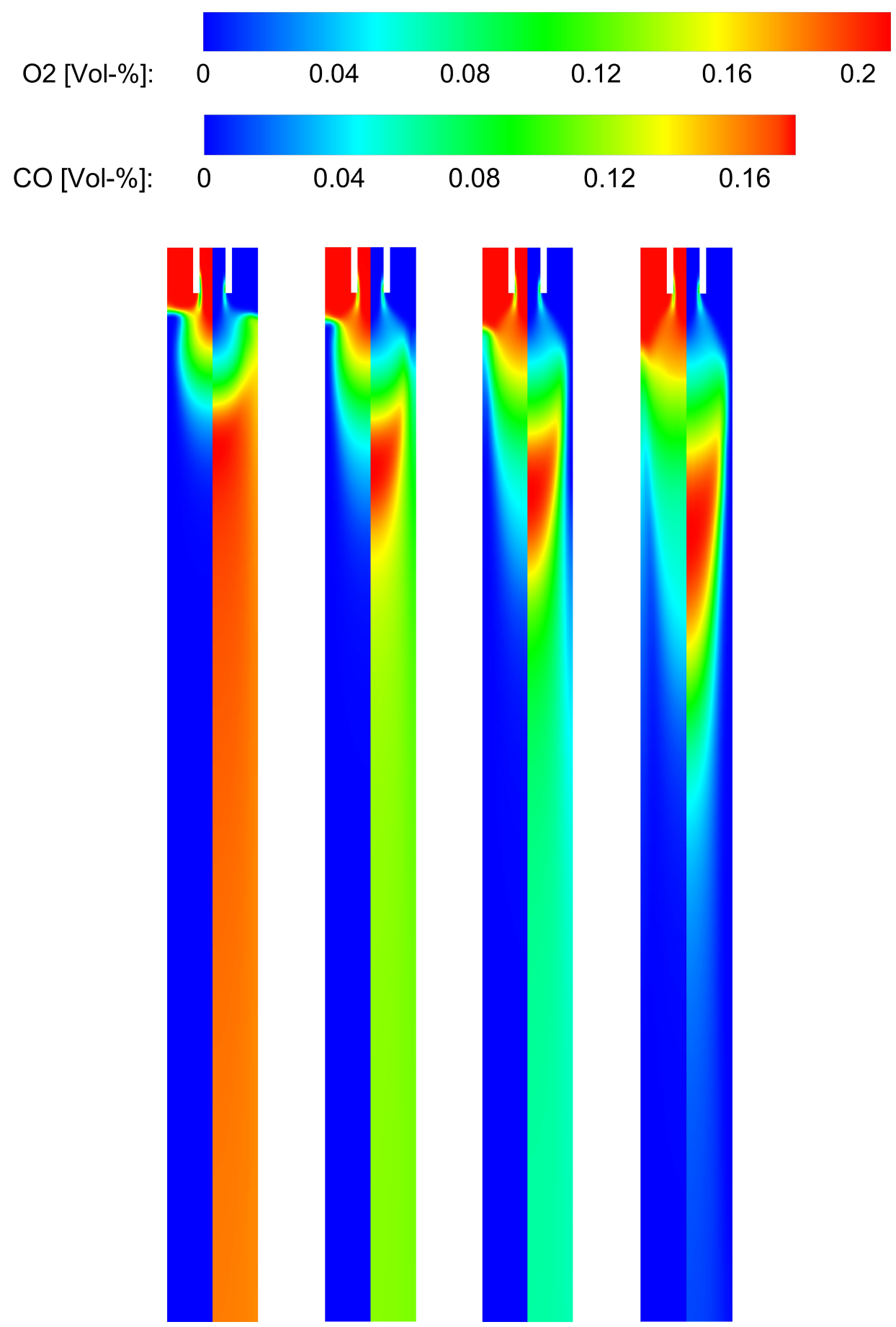

$$
\lambda=0.7 \quad \lambda=0.8 \quad \lambda=0.9 \quad \lambda=1.0
$$

Figure 5. Oxygen and carbon monoxide concentrations for the four air rations at wall temperature $1300{ }^{\circ} \mathrm{C}$ in the upper $800 \mathrm{~mm}$ of the reaction tube. The oxygen concentration is given on the left side, and the carbon monoxide concentration on the right side, for each air ratio in the assembled contours.

The calculated main species concentrations are compared to measurements to evaluate the accuracy of the prediction of the overall combustion process. Especially, the $\mathrm{CO}$ and $\mathrm{O}_{2}$ concentrations are important boundary conditions when calculating the concentrations of trace species. Trace species like $\mathrm{H}_{2} \mathrm{~S}, \mathrm{COS}$, and $\mathrm{HCl}$ are only formed in reducing atmosphere and they are oxidized very fast. All concentration values are given on dry basis in the following discussion. Error bars in the diagrams 
indicate a measurement uncertainty. The uncertainty of the measured species concentrations is estimated by a consideration of possible error sources and the used equipment. While the gas flows were controlled within a narrow tolerance range, fluctuations in the coal feed rate may occur. Fluctuations in the coal feed rate directly affected the ratio of fuel to oxygen and therefore the measured gas concentrations. For the experiments, a conservative estimate is $\pm 2 \%$ for the $\mathrm{CO}_{2}$ concentration and $\mathrm{CO}, \pm 100 \mathrm{ppm}$ for the total sulfur concentration and $\pm 10 \mathrm{ppm}$ for total chlorine species concentration. At each measurement point, at least 30 cycles of the mass spectrometer's measuring routine were recorded. Average concentration values are calculated from the measured sequences. In all concentration measurement results shown, error bars indicate the standard deviation of the recorded measurement data.

Figure 6 shows the concentrations of $\mathrm{CO}_{2}$ and $\mathrm{CO}$ for an air ratio of 1.0. The blue symbols indicate the measurements, and the red symbols indicate the simulation results. There is a good agreement in $\mathrm{CO}_{2}$ concentrations for all temperatures at both measuring planes. The $\mathrm{CO}_{2}$ concentration is $16.6 \mathrm{Vol}-\%$ for all wall temperatures. No significant difference in the $\mathrm{CO}_{2}$ concentration between the different wall temperatures indicates a complete burnout of the fuel also for the lower temperatures at air ratio 1.0. The calculated $\mathrm{CO}$ concentrations are almost zero for all temperatures at both measuring planes. The measured CO concentrations are between zero and 4.5 Vol- $\%$. For wall temperature $1000{ }^{\circ} \mathrm{C}$, there are $3.8 \mathrm{Vol}-\% \mathrm{CO}$ at measuring plane 1, and the $\mathrm{CO}$ concentration decreases downstream the reaction tube like it is predicted in the simulation. For wall temperature $1150{ }^{\circ} \mathrm{C}$, the measured CO concentration stays at about $4.4 \mathrm{Vol}-\%$. This is not reasonable because there is enough oxygen to oxidize all of the $\mathrm{CO}$ at air ratio of 1.0. At wall temperature $1300{ }^{\circ} \mathrm{C}$, there is no $\mathrm{CO}$ measured at measuring plane 1 and $4.5 \mathrm{Vol}-\%$ at lane 2 . The elevated CO concentrations are not present in the simulation results. They can be an indication of a delayed combustion. In this case, the residence time is not high enough to ensure a complete burnout. The measured CO concentrations are in contradiction to the operation conditions. The concentration should be small in case of good mixing and a complete combustion, like it is the case in the simulations.

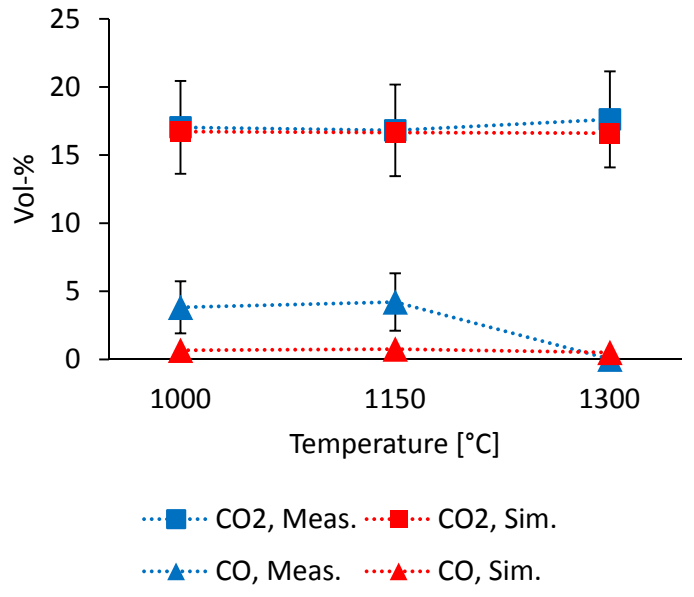

(a) Measuring plane 1

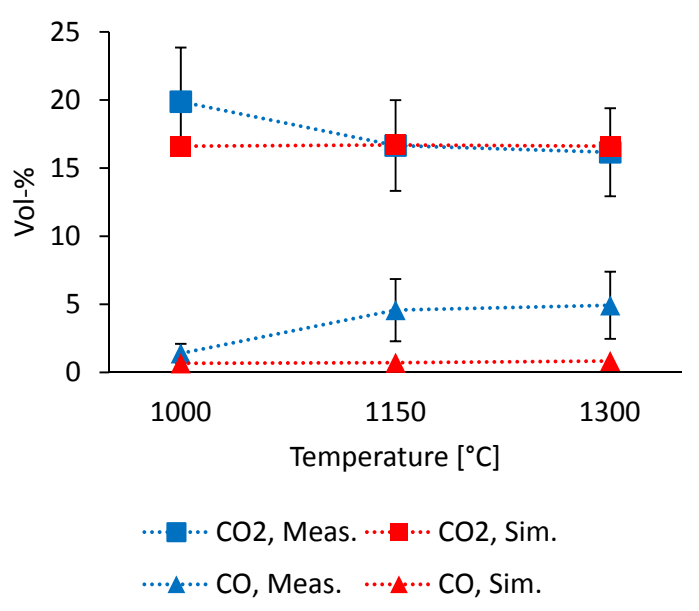

(b) Measuring plane 2

Figure 6. Measured and simulated $\mathrm{CO}_{2}$ and $\mathrm{CO}$ concentrations for air ratio 1.0.

Figure 7 shows the $\mathrm{CO}_{2}$ and $\mathrm{CO}$ concentrations for air ratio 0.9 over the three wall temperatures. The CO concentrations are now elevated up to $6 \mathrm{Vol}-\%$. For measuring plane 1, only one CO measurement is available, namely for wall temperature $1150{ }^{\circ} \mathrm{C}$. The simulation results show the same CO concentration of $5.6 \mathrm{Vol}-\%$. The measured CO concentration for wall temperature $1300{ }^{\circ} \mathrm{C}$ at measuring plane 2 is with $2.5 \mathrm{Vol}-\%$ unusually low and out of line. The calculated CO concentration is much higher with $5.6 \mathrm{Vol}-\%$. Over the three wall temperatures, the $\mathrm{CO}$ concentrations show a slightly increasing trend at air ratio 0.9. The measured and calculated $\mathrm{CO}_{2}$ concentrations are lower than at 
air ratio 1.0. The calculated $\mathrm{CO}_{2}$ concentrations are lower than the measurements, except for wall temperature of $1000{ }^{\circ} \mathrm{C}$ at measuring plane 1 . Nevertheless, all the other calculated concentrations are within the error bars of the measurements. Two measured $\mathrm{CO}_{2}$ concentrations are clearly out of line, namely at wall temperature $1300{ }^{\circ} \mathrm{C}$ at measuring plane 1 and at wall temperature $1000{ }^{\circ} \mathrm{C}$ at measuring plane 2. With $20 \mathrm{Vol}-\%$, they are higher than at air ratio 1.0. The reason could be an elevated coal mass flow during the measurements or measurement inaccuracy. Despite this, the major part of the measurements and simulation results are in good agreement for the air ratio of 0.9.

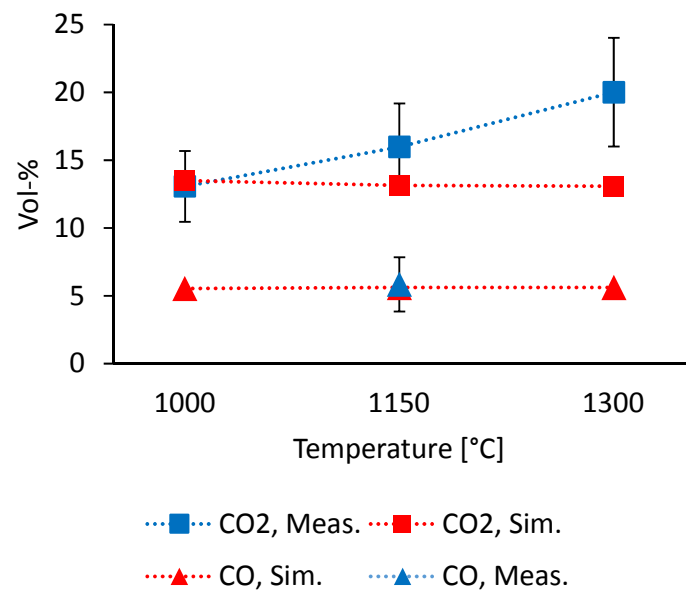

(a) Measuring plane 1

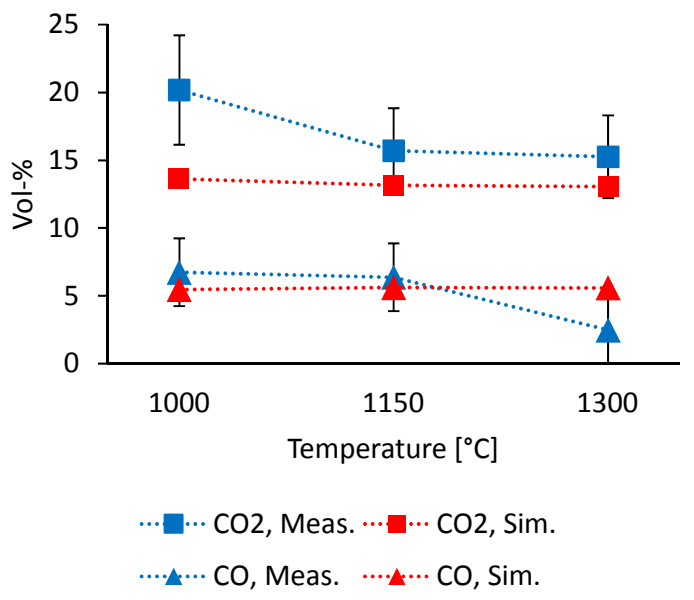

(b) Measuring plane 2

Figure 7. Measured and simulated $\mathrm{CO}_{2}$ and $\mathrm{CO}$ concentrations for air ratio 0.9.

To have a closer look at the effect of a lower air ratio, Figures 8 and 9 show the $\mathrm{CO}$ and the $\mathrm{CO}_{2}$ concentrations for all four air ratios for wall temperature of $1300{ }^{\circ} \mathrm{C}$. The $\mathrm{CO}$ concentrations (c.f. Figure 8) show a decreasing trend from 15 Vol- $\%$ to 0 Vol- $\%$ with increasing air ratio in the simulations. The measured concentration for air ratio 0.9 is higher than for air ratio 0.8 . It is believed that the $\mathrm{CO}$ measurement does not represent the real condition for air ratio 0.9 . The simulation results show a clear linear behavior because the oxygen supply is reduced with decreasing air ratio, and the coal mass flow was kept constant. Almost all calculated concentrations are within the error bars of the measurements.

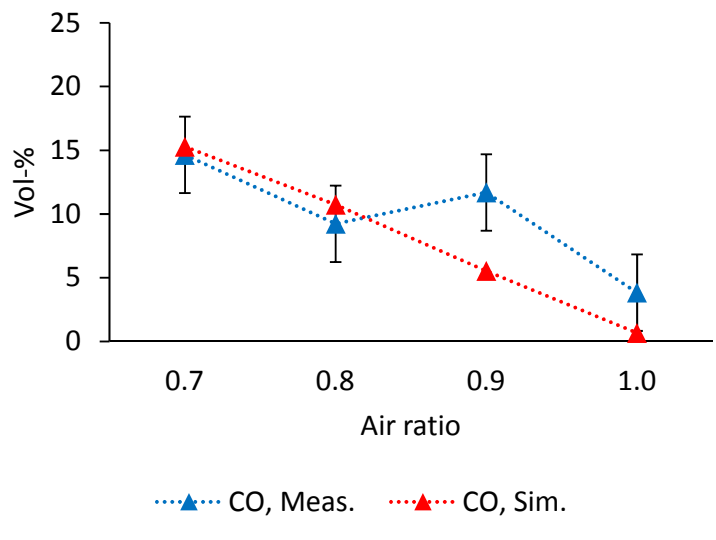

(a) Measuring plane 1

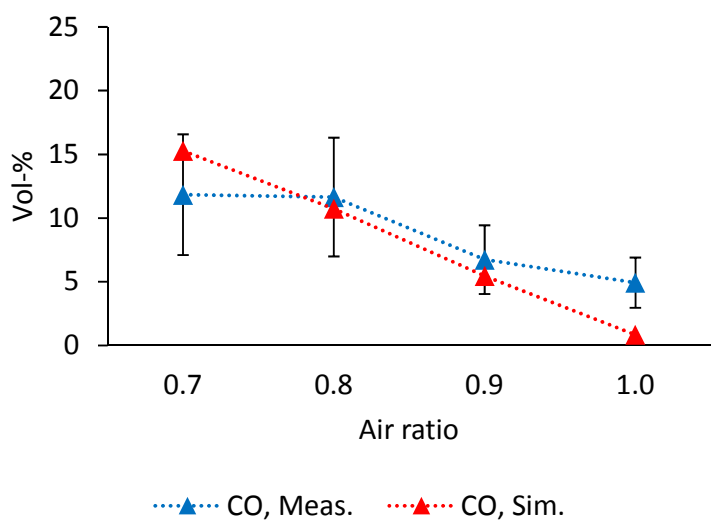

(b) Measuring plane 2

Figure 8. Measured and simulated CO concentrations for wall temperature $1300^{\circ} \mathrm{C}$.

The $\mathrm{CO}_{2}$ concentrations show a opposite behavior compared to the $\mathrm{CO}$ concentrations. With increasing air ratios, the $\mathrm{CO}_{2}$ concentrations increase from $5 \mathrm{Vol}-\%$ to $16.6 \mathrm{Vol}-\%$ in the simulations. 
The measurements show the same trend, except for air ratio 0.7. At measuring plane 2, the measured $\mathrm{CO}_{2}$ concentrations is with $12.5 \mathrm{Vol}-\%$ even higher than at air ratio 0.8 . The measured $\mathrm{CO}_{2}$ concentration is also elevated at measuring plane 1 for air ratio 0.7 . A temporary higher coal feed rate may be the reason for this increased concentrations. For the other three air ratios, there is a very good agreement between measurements and simulation results at both measuring planes.

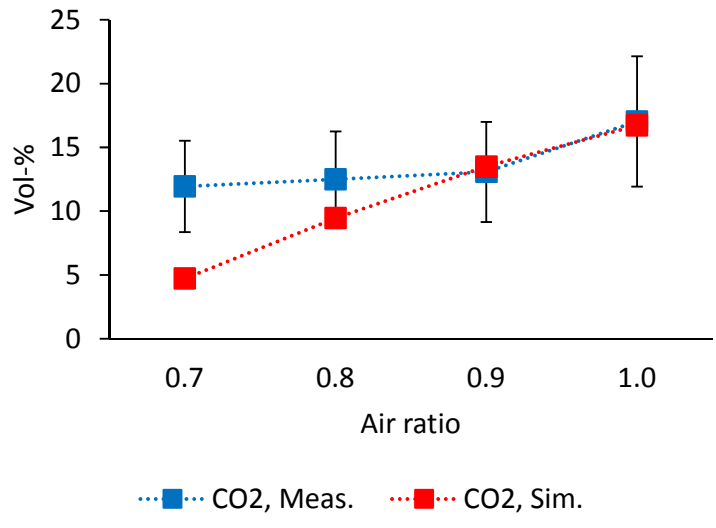

(a) Measuring plane 1

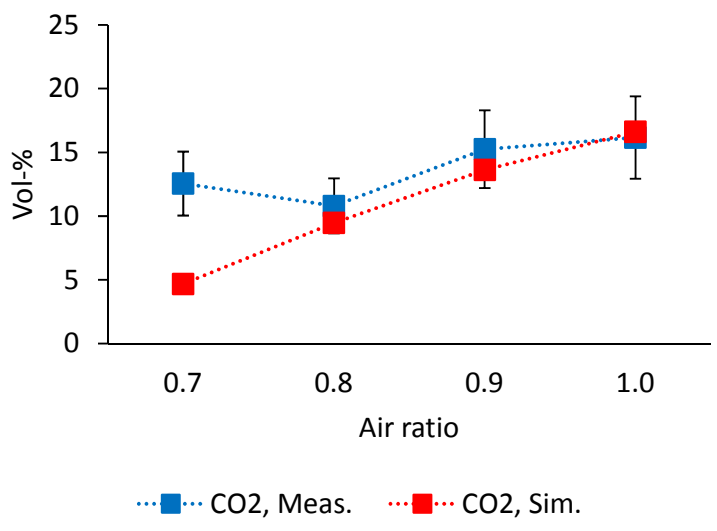

(b) Measuring plane 2

Figure 9. Measured and simulated $\mathrm{CO}_{2}$ concentrations for wall temperature $1300{ }^{\circ} \mathrm{C}$.

A reason for the high $\mathrm{CO}$ concentrations at some operation points, which seem to be out of line (e.g., air ratio 1.0 c.f. Figure 6 or air ratio 0.9 in Figure 8), despite a sufficient oxygen amount could be insufficient mixing in the reaction tube. A fully developed pipe flow is achieved in the tube downstream the injection nozzle. The mass transfer in radial direction seems to be too small to allow a complete burnout. Hence not all $\mathrm{CO}$ is oxidized. The overall agreement between simulation results and measurement is satisfying. The boundary conditions for the trace species calculations are provided sufficiently accurate by the reaction model.

\subsection{Trace Species}

Sulfur and chlorine species, like $\mathrm{H}_{2} \mathrm{~S}, \mathrm{COS}$, and $\mathrm{HCl}$, play a major role in high temperature corrosion processes [3,4]. They occur only in small amounts off parts per million (ppm) in coal fired furnaces. The simulation results are discussed regarding the concentrations of $\mathrm{SO}_{2}, \mathrm{H}_{2} \mathrm{~S}, \mathrm{COS}$, and $\mathrm{HCl}$ in this section. Figure 10 shows the $\mathrm{H}_{2} \mathrm{~S}$ and $\mathrm{SO}_{2}$ concentrations for wall temperature $1300^{\circ} \mathrm{C}$ for all four air ratios.
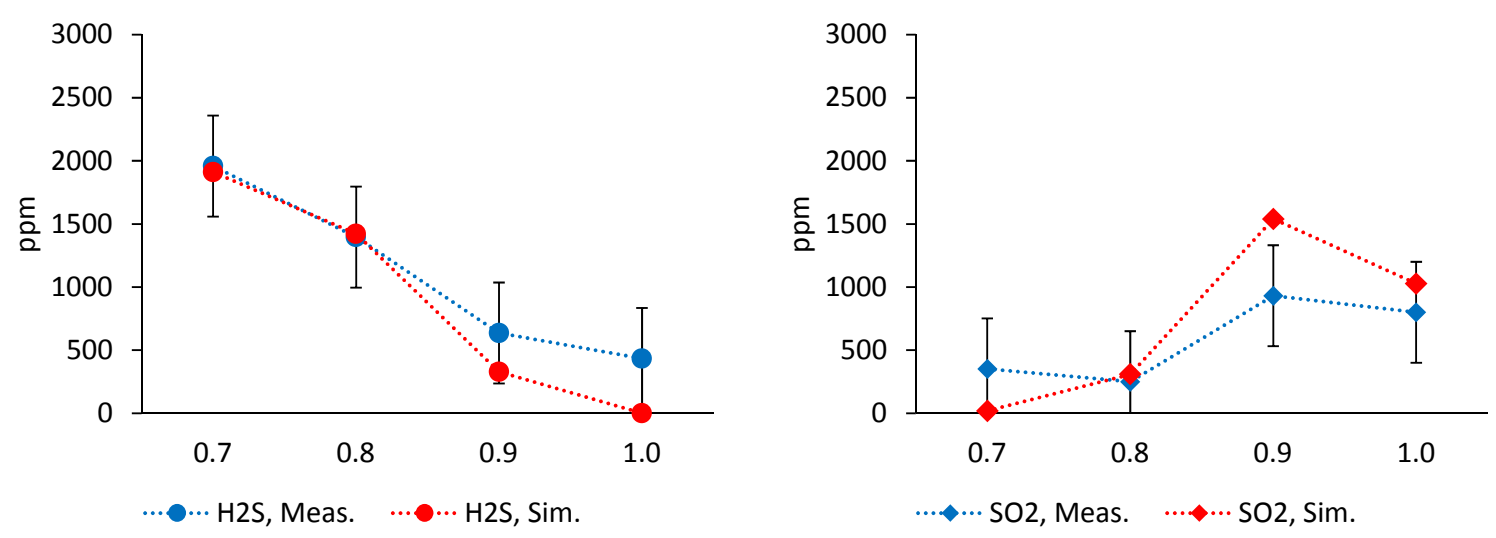

Figure 10. Measured and simulated $\mathrm{H}_{2} \mathrm{~S}$ and $\mathrm{SO}_{2}$ concentrations for wall temperature $1300{ }^{\circ} \mathrm{C}$ at measuring plane 2 . 
$\mathrm{H}_{2} \mathrm{~S}$ concentrations increase with decreasing air ratio. $\mathrm{SO}_{2}$ concentrations show an opposite trend. The $\mathrm{H}_{2} \mathrm{~S}$ concentrations rise in the reducing atmospheres along with the $\mathrm{CO}$ concentrations, like it is depicted in Figure 8. With lack of oxygen, $\mathrm{H}_{2} \mathrm{~S}$ cannot be oxidized, and $\mathrm{SO}_{2}$ is in addition converted to $\mathrm{H}_{2} \mathrm{~S}$ under reducing conditions. Both, measurements and simulation results, show a higher $\mathrm{SO}_{2}$ concentration for air ratio 0.9 than for air ratio 1.0. The sulfur release in form of $\mathrm{SO}_{2}$ is elevated. In the reducing atmosphere, the $\mathrm{SO}_{2}$ is reduced to $\mathrm{H}_{2} \mathrm{~S}$. This effect is under predicted in the simulation for a high air ratio and the calculated $\mathrm{SO}_{2}$ concentration is higher than the measurement. Nevertheless, for air ratio 0.8 , the results are in good agreement with the measurements. For air ratio 0.7 , almost no $\mathrm{SO}_{2}$ is present in the simulation. The measurements show a concentration of $350 \mathrm{ppm}$ $\mathrm{SO}_{2}$ for air ratio 0.7 , which is a higher concentration than for air ratio 0.8 . The result is still acceptable because the calculated $\mathrm{SO}_{2}$ concentration is within the error margin of the measurement. $\mathrm{The}_{2} \mathrm{~S}$ concentration rises up to $2000 \mathrm{ppm}$ for air ratio 0.7 and declines to zero for air ratio 1.0 in the simulation. The measurements show $400 \mathrm{ppm}_{2} \mathrm{~S}$ for air ratio 1.0. The high concentration can not be explained with the operation conditions. Due to the fully developed pipe flow in the reaction tube, there might be bad mixing in the tube, and not all $\mathrm{H}_{2} \mathrm{~S}$ is oxidized. The same is observed for the $\mathrm{CO}$ concentrations at air ratio 1.0 (c.f. Figure 6 The simulation results and the measurements are in good agreement for all air ratios, whereby the three substoichiometric air ratios are of particular importance.

Figure 11 shows the $\mathrm{H}_{2} \mathrm{~S}$ and $\mathrm{SO}_{2}$ concentrations for the air ratios $0.7,0.8$, and 0.9 for the three wall temperatures at measuring plane 2 . The further discussion of the trace species will be limited to the substoichiometric air ratios $0.7,0.8$, and 0.9 because for air ratio 1.0 no significant amounts of the trace species occur. The $\mathrm{H}_{2} \mathrm{~S}$ concentrations show a peak for wall temperature $1150{ }^{\circ} \mathrm{C}$. Lower amounts of $\mathrm{H}_{2} \mathrm{~S}$ are present for the other wall temperatures. For elevated temperatures, the sulfur release is higher than for lower temperatures. The reaction velocity is highly temperature dependent; therefore, at $1300{ }^{\circ} \mathrm{C}$, the $\mathrm{H}_{2} \mathrm{~S}$ can react faster to other sulfur species. This results in lower $\mathrm{H}_{2} \mathrm{~S}$ concentrations at $1300{ }^{\circ} \mathrm{C}$, although the sulfur release from the coal and minerals is high. With decreasing air ratio, the $\mathrm{H}_{2} \mathrm{~S}$ concentrations increase slightly for all temperatures. The simulation predicts the $\mathrm{H}_{2} \mathrm{~S}$ concentrations accurately. Just for wall temperature $1000^{\circ}$ at air ratio 0.9 , the calculated $\mathrm{H}_{2} \mathrm{~S}$ concentrations are clearly higher than the measurement. The simulation over predicts the sulfur release for this condition and the oxidation of $\mathrm{H}_{2} \mathrm{~S}$ to $\mathrm{SO}_{2}$ is under predicted. This can also bee seen by the elevated $\mathrm{SO}_{2}$ concentration in the measurements for the wall temperature of $1000^{\circ}$ at air ratio 0.9. The calculated $\mathrm{SO}_{2}$ concentrations is almost zero, clearly lower than the measurement. For wall temperature $1150^{\circ}$ at air ratio 0.8 , the calculated $\mathrm{H}_{2} \mathrm{~S}$ concentration is also higher than the measurement. At this point, the measured and calculated $\mathrm{SO}_{2}$ concentrations are in good agreement. Either the sulfur release is overpredicted or the transformation of $\mathrm{H}_{2} \mathrm{~S}$ to other sulfur species is underpredicted by the gas phase reactions in the simulation. Overall, the simulation results for $\mathrm{H}_{2} \mathrm{~S}$ show a good agreement with the measurements. Along with the $\mathrm{H}_{2} \mathrm{~S}$ concentrations, the $\mathrm{SO}_{2}$ concentrations are also well predicted because $\mathrm{H}_{2} \mathrm{~S}$ and $\mathrm{SO}_{2}$ are linked through the gas phase reactions.

Figure 12a shows the concentrations of COS for the four air ratios at wall temperature $1000{ }^{\circ} \mathrm{C}$. The right diagram (Figure 12b) depicts the COS concentrations for the three wall temperatures at air ratio 0.8 . The measured COS concentrations are between $80 \mathrm{ppm}$ and $400 \mathrm{ppm}$. The measurements show slightly increasing COS concentrations with decreasing air ratio. There is a good agreement between the measurements and the simulation results for the air ratios 0.8 to 1.0. For air ratio 0.7, the calculated concentration is too low. The simulation results show also increasing COS concentrations with air ratio decreasing from 1.0 to 0.9 , but then the calculated concentrations decrease with further decreasing air ratio. This is contradictory to the $\mathrm{H}_{2} \mathrm{~S}$ concentrations (c.f. Figure 10), which are increasing with decreasing air ratio. Figure $12 \mathrm{~b}$ illustrates the $\mathrm{COS}$ concentrations for the different wall temperatures at air ratio 0.8. A trend similar to the $\mathrm{H}_{2} \mathrm{~S}$ concentrations (c.f. Figure 11) can be recognized with elevated concentrations at $1150{ }^{\circ} \mathrm{C}$. The concentration at $1150{ }^{\circ} \mathrm{C}$ is slightly higher than for $1000{ }^{\circ} \mathrm{C}$ and $1300^{\circ} \mathrm{C}$. The simulation results show the same trend, but the concentrations are between $150 \mathrm{ppm}$ and $200 \mathrm{ppm}$ lower than the measurements. Since the $\mathrm{H}_{2} \mathrm{~S}$ concentrations are well 
predicted, the reasons for the deviations in the COS concentrations are probably located in the COS subset of the gas phase reaction mechanism. In general, $\mathrm{COS}$ can be consumed either by reaction with the radical pool, by thermal decomposition and by reaction with stable species, such as $\mathrm{O}_{2}$ or $\mathrm{H}_{2} \mathrm{O}$. Therefore, the COS reaction subset needs further review.

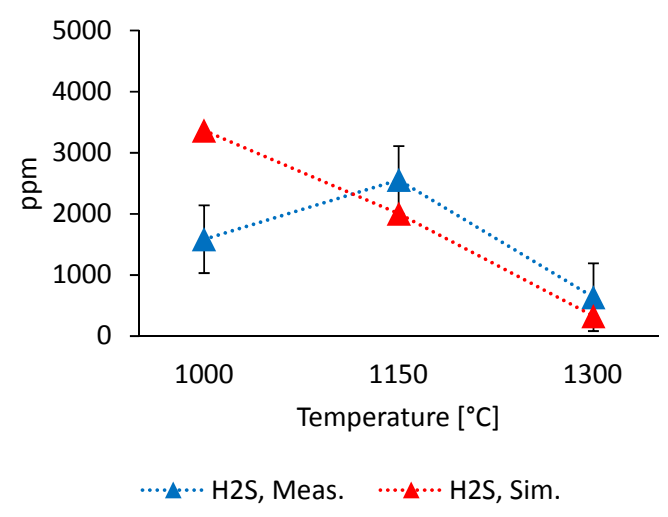

(a) Air ratio 0.9

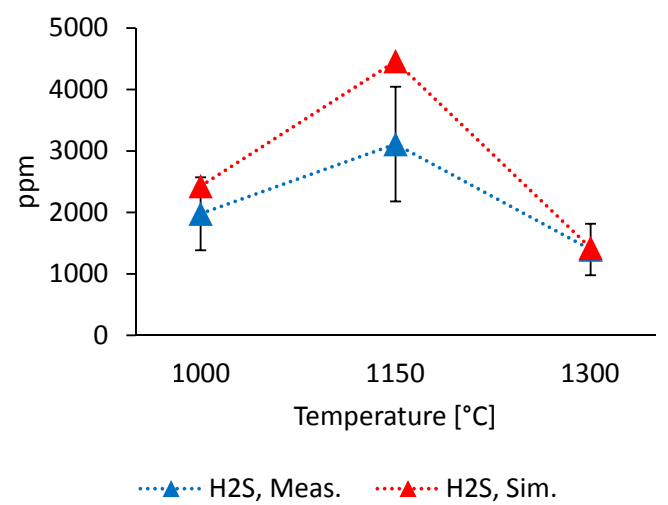

(c) Air ratio 0.8

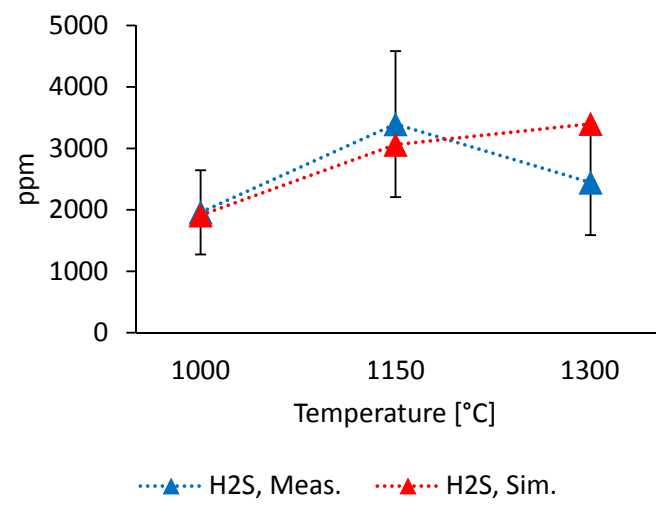

(e) Air ratio 0.7

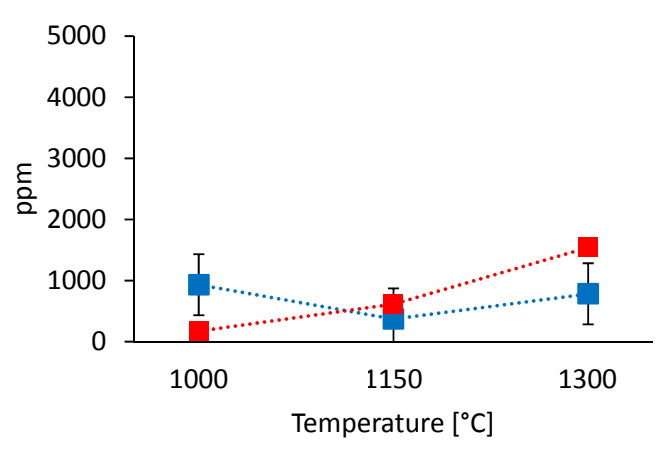

SO2, Meas. …… SO2, Sim.

(b) Air ratio 0.9

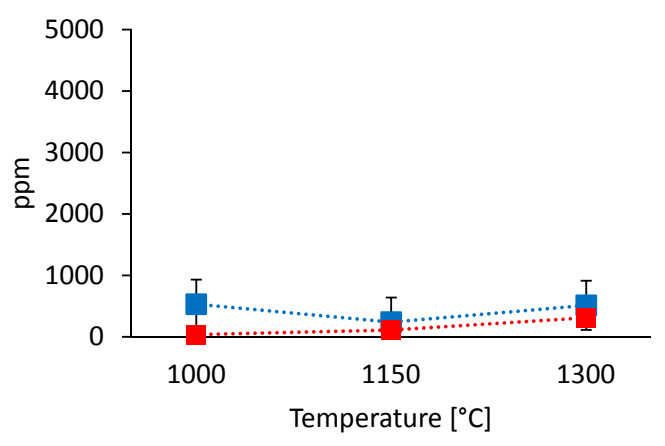

SO2, Meas. …… SO2, Sim.

(d) Air ratio 0.8

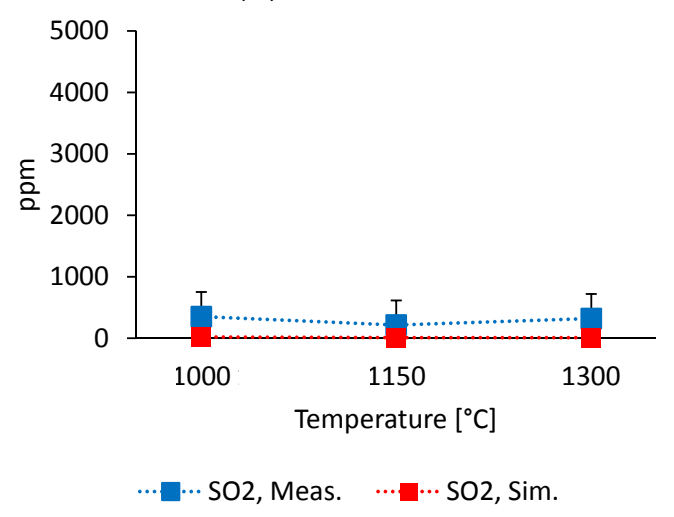

(f) Air ratio 0.7

Figure 11. Measured and simulated $\mathrm{H}_{2} \mathrm{~S}$ and $\mathrm{SO}_{2}$ concentrations at measuring plane 2 . 


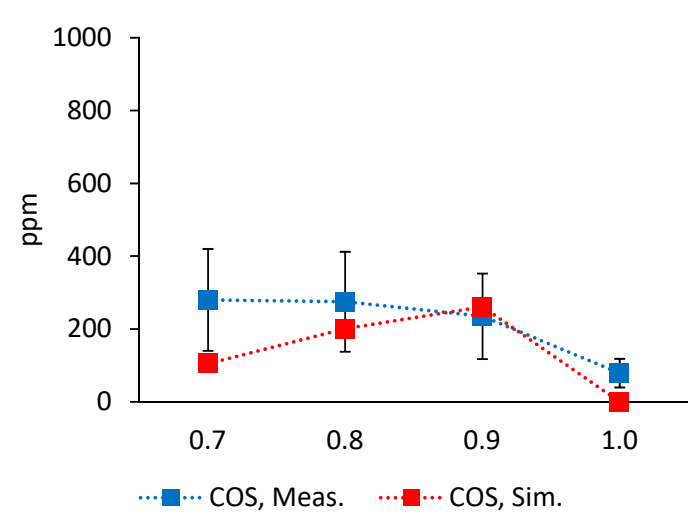

(a) Wall temperature $1000{ }^{\circ} \mathrm{C}$, measuring plane 2

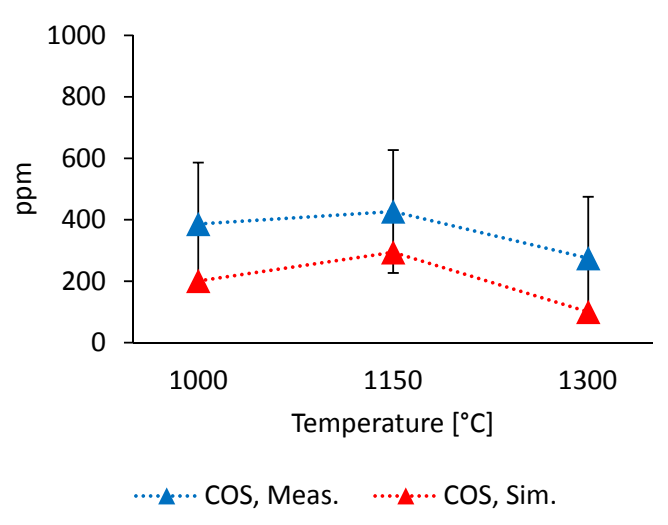

(b) Air ratio 0.8, measuring plane 2

Figure 12. Measured and simulated $\mathrm{HCl}$ concentrations.

Calculated $\mathrm{HCl}$ concentrations are presented for all four air ratios at wall temperature $1300{ }^{\circ} \mathrm{C}$ in Figure 13a. There a low concentrations for the air ratios 1.0 and 0.9 and higher concentrations for the air ratios 0.8 and 0.7. The highest measured and calculated concentrations occur at air ratio 0.8 . At this point, also the biggest deviation between simulation and measurements appear. The agreement is good for the other three air ratios. Figure $13 \mathrm{~b}$ depicts the $\mathrm{HCl}$ concentration for the three wall temperatures at air ratio 1.0. The calculated $\mathrm{HCl}$ concentration is too low for wall temperatures of $1150{ }^{\circ} \mathrm{C}$. The deviation is in the range of $150 \mathrm{ppm}$. Nevertheless, there is a very good agreement between simulation results and measurements for wall temperatures $1000^{\circ} \mathrm{C}$ and $1300{ }^{\circ} \mathrm{C}$. The model is capable of predicting the $\mathrm{HCl}$ concentration for high and low temperatures and fails at the middle temperature of $1150^{\circ} \mathrm{C}$.

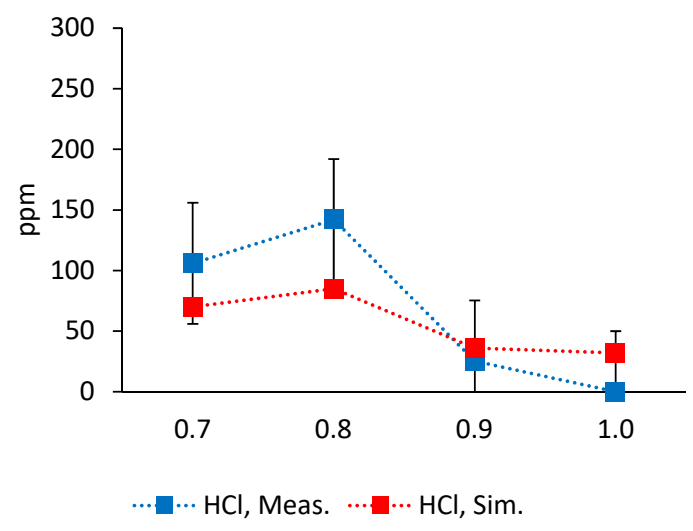

(a) Wall temperature $1300{ }^{\circ} \mathrm{C}$, measuring plane 2

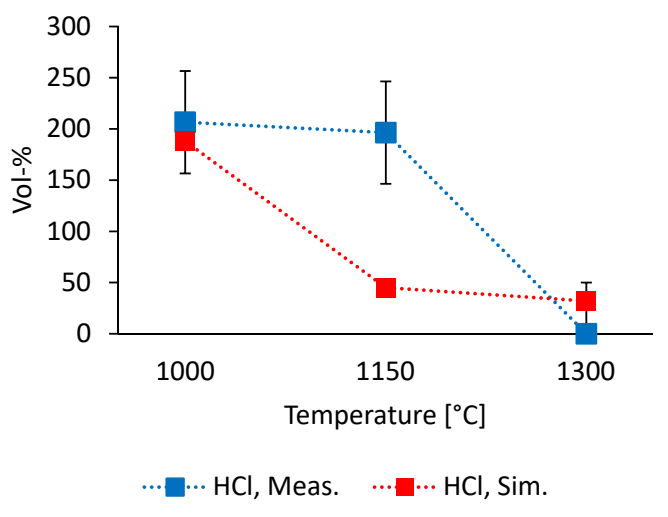

(b) Air ratio 1.0, measuring plane 2

Figure 13. Measured and simulated $\mathrm{HCl}$ concentrations.

\section{Conclusions}

In the present work, 3D CFD simulations of a entrained flow reactor were carried out. A complex mathematical model of pulverized coal combustion including mineral matter transformation and sulfur and chlorine release was presented to predict and assess the high temperature corrosion risk in coal fired furnaces. Measurement data from the entrained flow reactor was considered for evaluating an advanced model for CFD simulations of coal combustion chemistry. The entrained flow reactor data is especially well suited for this purpose since experimental measurements inside the reactor are available and the boundary conditions are well known. This detailed information is crucial for the assessment of the CFD model's predictive capability for sulfur and chlorine species release and formation. Three different wall temperatures of the reactor and four different air ratios were 
investigated, resulting in 12 different cases. The main focus of the work was the modeling of the sulfur and chlorine species behavior during the pulverized coal combustion. The following main conclusions can be drawn from the results reported in this paper.

The concentrations of the main gas species $\mathrm{CO}_{2}$ and $\mathrm{CO}$ show overall a good agreement with the measurements. They lay the foundation for the calculation of trace species concentrations. The applied simulation model delivered good results for $\mathrm{H}_{2} \mathrm{~S}$ and $\mathrm{SO}_{2}$ concentrations at substoichiometric conditions. Some of the calculated COS concentrations are lower than the measurements, there is an agreement at other points. Since the $\mathrm{H}_{2} \mathrm{~S}$ concentrations are well predicted, the reasons for the deviations in the COS concentrations are probably located in the gas phase reaction mechanism, more precisely in the COS subset. The same conclusion can be drawn for the $\mathrm{HCl}$ concentrations. Calculated $\mathrm{HCl}$ concentrations are too low for some operation points. There is a good agreement at some other operation points.

For future work, ash particle need to be analyzed to evaluate the simulation of the chlorine release. With this information, the chlorine release model and the gas phase mechanism can be adapted. Evaluation of high temperature corrosion risk is still possible because the occurrence of $\mathrm{H}_{2} \mathrm{~S}, \mathrm{COS}$, and $\mathrm{HCl}$ is a sign for possible corrosion attack, even if the exact concentrations may not be known.

Author Contributions: Conceptualization, M.v.B.; software, M.v.B.; validation, M.v.B., C.Y. and L.F.; investigation, C.Y. and L.F.; writing-original draft preparation, M.v.B.; writing-review and editing, C.Y.; supervision, J.S. and B.E.; funding acquisition, B.E. All authors have read and agreed to the published version of the manuscript.

Funding: Funded by the Deutsche Forschungsgemeinschaft (DFG, German Research Foundation)Projektnummer 215035359-TRR 129.

Acknowledgments: Funded by the Deutsche Forschungsgemeinschaft (DFG, German Research Foundation) Projektnummer 215035359-TRR 129. Calculations for this research were conducted on the Lichtenberg high performance computer of the TU Darmstadt.

Conflicts of Interest: The authors declare no conflict of interest.

\section{Abbreviations}

The following abbreviations are used in this manuscript:

$\begin{array}{ll}\text { Roman } & \\ X & \text { mole fraction [-] } \\ p & \text { pressure [Pa] } \\ R & \text { ideal gas constant }[8314 \mathrm{~J} / \mathrm{kmol} \mathrm{K}] \\ T & \text { temperature [K] } \\ A & \text { pre-exponential factor } \\ E & \text { activation energy }[\mathrm{kJ} / \mathrm{mol}] \\ k & \text { rate constant } \\ D & \text { difusion constant } \\ d & \text { particle diameter }[\mathrm{m}] \\ \text { Greek } & \\ \kappa & \text { absorption coefficient }[1 / m] \\ \sigma & \text { scattering coefficient }[1 / m] \\ \epsilon & \text { emissivity [-] } \\ \Phi & \text { phase function [-] } \\ \text { Abbreviations } & \\ \text { CFD } & \text { Computational Fluid Dynamics } \\ \text { WSGG } & \text { weighted sum of gray gases } \\ \text { DO } & \text { Discrete Ordinates } \\ \text { RC } & \text { raw coal } \\ \text { Vol-\% } & \text { volume percent }\end{array}$




$\begin{array}{ll}\text { Subscripts } & \\ \text { kin } & \text { kinetic } \\ \text { diff } & \text { diffusion } \\ \mathrm{p} & \text { particle } \\ \mathrm{g} & \text { gas (species) } \\ \mathrm{s} & \text { solid } \\ \mathrm{ub} & \text { unburnt } \\ \mathrm{w} & \text { wall } \\ \mathrm{ch} & \text { chemical }\end{array}$

\section{Appendix A}

Complete reaction mechanism for the gas phase:

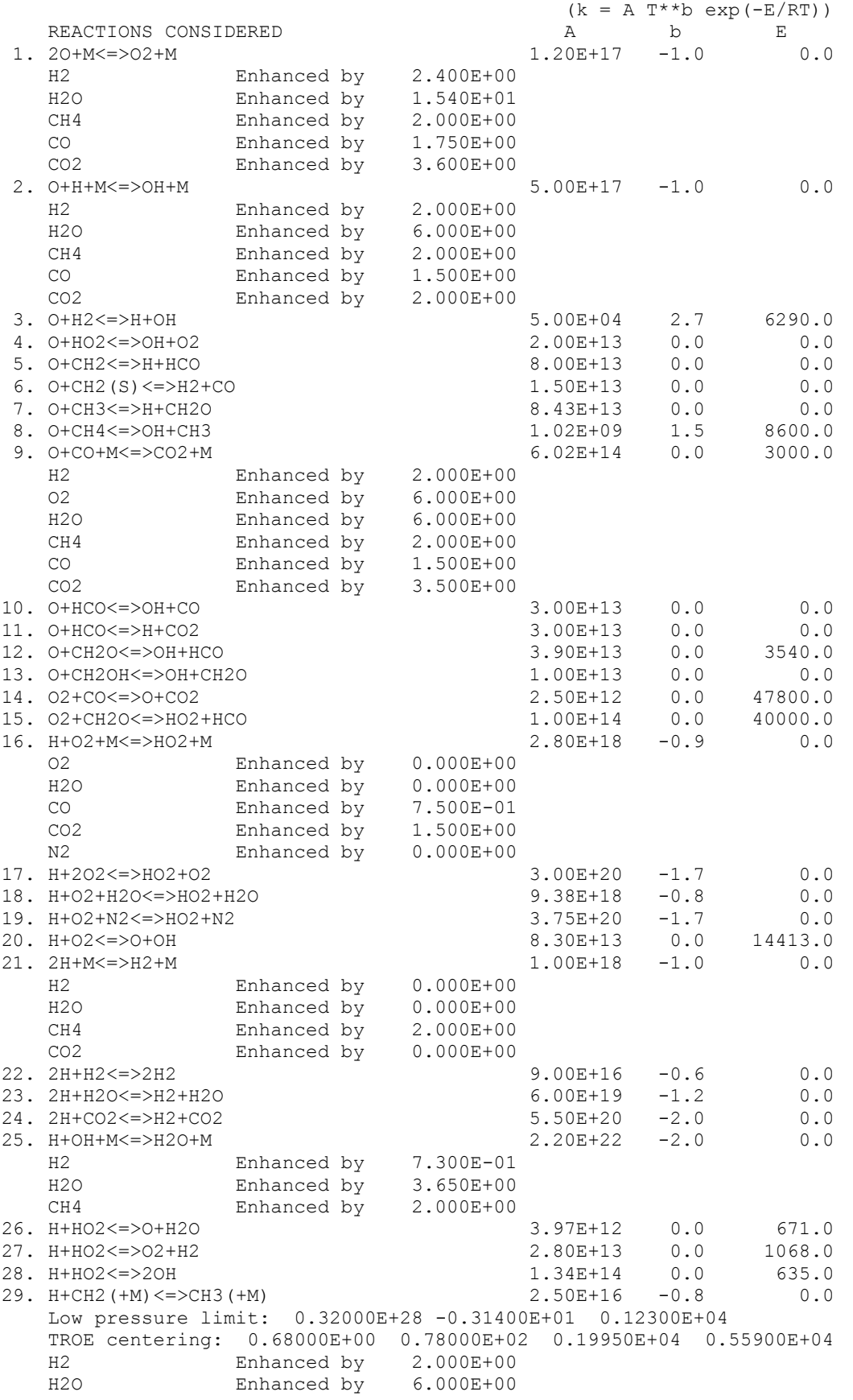

Figure A1. Gas phase reaction mechanism. 


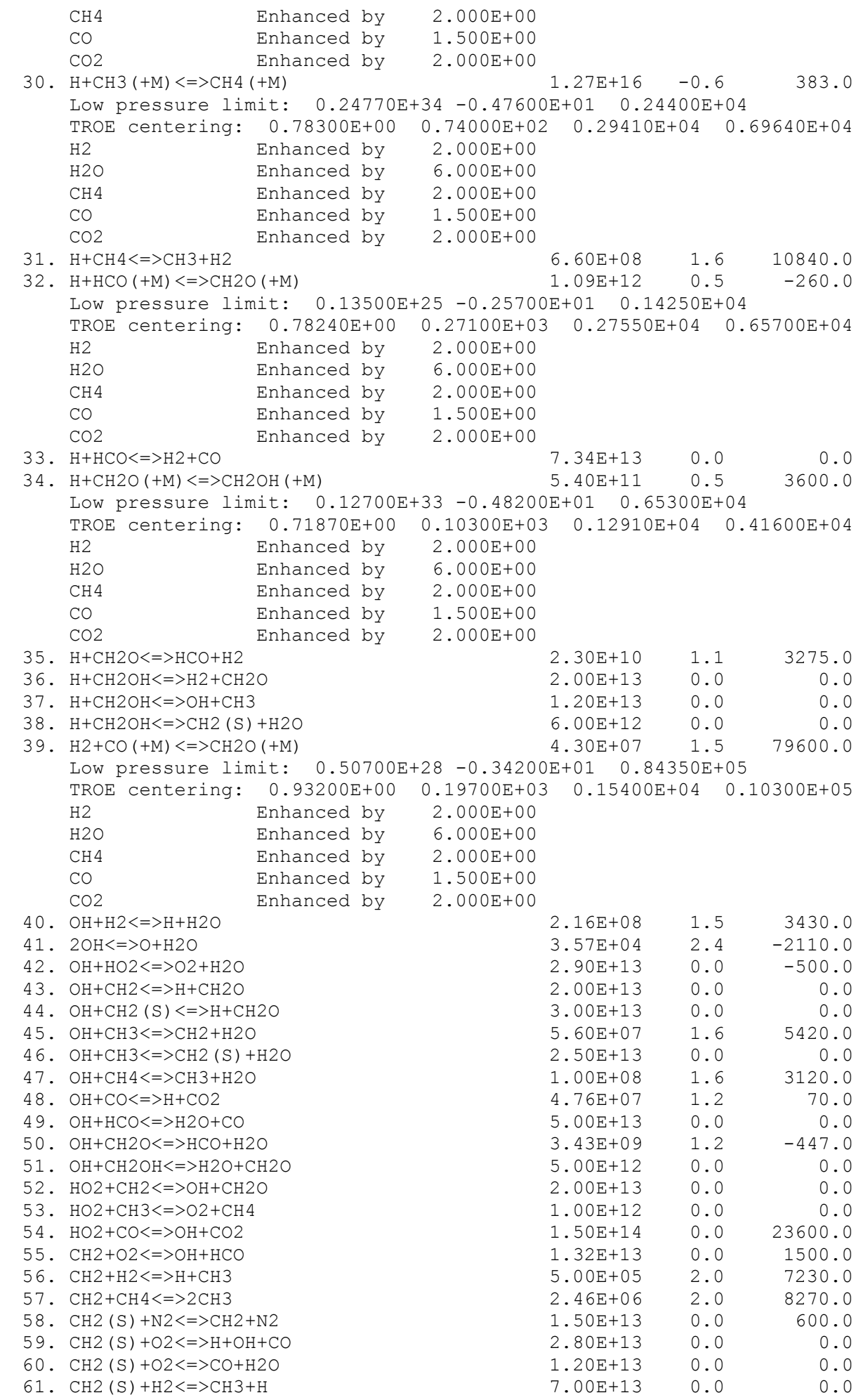

Figure A2. Gas phase reaction mechanism. 


\begin{tabular}{|c|c|c|c|c|c|c|}
\hline 62 . & \multicolumn{3}{|c|}{$\mathrm{CH} 2(\mathrm{~S})+\mathrm{H} 2 \mathrm{O}<=>\mathrm{CH} 2+\mathrm{H} 2 \mathrm{O}$} & $3.00 \mathrm{E}+13$ & 0.0 & 0.0 \\
\hline 63. & \multicolumn{3}{|c|}{$\mathrm{CH} 2(\mathrm{~S})+\mathrm{CH} 4<=>2 \mathrm{CH} 3$} & $1.60 \mathrm{E}+13$ & 0.0 & -570.0 \\
\hline 64. & \multicolumn{3}{|l|}{$\mathrm{CH} 2(\mathrm{~S})+\mathrm{CO}<=>\mathrm{CH} 2+\mathrm{CO}$} & $9.00 \mathrm{E}+12$ & 0.0 & 0.0 \\
\hline 65. & \multicolumn{3}{|c|}{$\mathrm{CH} 2(\mathrm{~S})+\mathrm{CO} 2<=>\mathrm{CH} 2+\mathrm{CO} 2$} & $7.00 \mathrm{E}+12$ & 0.0 & 0.0 \\
\hline 66. & \multicolumn{3}{|c|}{$\mathrm{CH} 2(\mathrm{~S})+\mathrm{CO} 2<=>\mathrm{CO}+\mathrm{CH} 2 \mathrm{O}$} & 1. $40 \mathrm{E}+13$ & 0.0 & 0.0 \\
\hline 67. & \multicolumn{3}{|c|}{$\mathrm{CH} 3+\mathrm{O} 2<=>\mathrm{OH}+\mathrm{CH} 2 \mathrm{O}$} & $3.60 \mathrm{E}+10$ & 0.0 & 8940.0 \\
\hline 68 . & \multicolumn{3}{|l|}{$\mathrm{CH} 3+\mathrm{HCO}<=>\mathrm{CH} 4+\mathrm{CO}$} & $2.65 E+13$ & 0.0 & 0.0 \\
\hline 69. & \multicolumn{3}{|l|}{$\mathrm{CH} 3+\mathrm{CH} 2 \mathrm{O}<=>\mathrm{HCO}+\mathrm{CH} 4$} & $3.32 \mathrm{E}+03$ & 2.8 & 5860.0 \\
\hline 70 & \multicolumn{3}{|l|}{$\mathrm{HCO}+\mathrm{H} 2 \mathrm{O}<=>\mathrm{H}+\mathrm{CO}+\mathrm{H} 2 \mathrm{O}$} & $2.24 \mathrm{E}+18$ & -1.0 & 17000.0 \\
\hline & \multicolumn{3}{|l|}{$\mathrm{HCO}+\mathrm{M}<=>\mathrm{H}+\mathrm{CO}+\mathrm{M}$} & $1.87 \mathrm{E}+17$ & -1.0 & 17000.0 \\
\hline & $\mathrm{H} 2$ & Enhanced by & $2.000 \mathrm{E}+00$ & & & \\
\hline & $\mathrm{H} 2 \mathrm{O}$ & Enhanced by & $0.000 \mathrm{E}+00$ & & & \\
\hline & $\mathrm{CH} 4$ & Enhanced by & $2.000 \mathrm{E}+00$ & & & \\
\hline & $\mathrm{CO}$ & Enhanced by & 1. $500 \mathrm{E}+00$ & & & \\
\hline & $\mathrm{CO} 2$ & Enhanced by & $2.000 \mathrm{E}+00$ & & & \\
\hline 72 . & \multicolumn{3}{|c|}{$\mathrm{HCO}+\mathrm{O} 2<=>\mathrm{HO} 2+\mathrm{CO}$} & $7.60 \mathrm{E}+12$ & 0.0 & 400.0 \\
\hline 73 & \multicolumn{3}{|l|}{$\mathrm{CH} 2 \mathrm{OH}+\mathrm{O} 2<=>\mathrm{HO} 2+\mathrm{CH} 2 \mathrm{O}$} & $1.80 \mathrm{E}+13$ & 0.0 & 900.0 \\
\hline 74 & \multicolumn{3}{|c|}{$\mathrm{H} 2 \mathrm{~S}+\mathrm{M}=\mathrm{S}+\mathrm{H} 2+\mathrm{M}$} & $1.60 \mathrm{E}+24$ & -2.6 & 44800.0 \\
\hline & N2 & Enhanced by & $1.500 \mathrm{E}+00$ & & & \\
\hline & $\mathrm{SO} 2$ & Enhanced by & $1.000 \mathrm{E}+01$ & & & \\
\hline & $\mathrm{H} 2 \mathrm{O}$ & Enhanced by & $1.000 \mathrm{E}+01$ & & & \\
\hline 75 . & $\mathrm{H} 2 \mathrm{~S}+\mathrm{H}=\mathrm{SH}+\mathrm{H} 2$ & & & 1.20E+07 & 2.1 & 350.0 \\
\hline 76 . & $\mathrm{H} 2 \mathrm{~S}+\mathrm{O}=\mathrm{SH}+\mathrm{OH}$ & & & $7.50 \mathrm{E}+07$ & 1.8 & 1460.0 \\
\hline 77. & $\mathrm{H} 2 \mathrm{~S}+\mathrm{OH}=\mathrm{SH}+\mathrm{H} 2 \mathrm{O}$ & & & $2.70 \mathrm{E}+12$ & 0.0 & 0.0 \\
\hline 78 . & $\mathrm{H} 2 \mathrm{~S}+\mathrm{S}=2 \mathrm{SH}$ & & & $8.30 \mathrm{E}+13$ & 0.0 & 3700.0 \\
\hline 79. & $\mathrm{H} 2 \mathrm{~S}+\mathrm{S}=\mathrm{HS} 2+\mathrm{H}$ & & & $2.00 \mathrm{E}+13$ & 0.0 & 3723.8 \\
\hline 80 & $\mathrm{~S}+\mathrm{H} 2=\mathrm{SH}+\mathrm{H}$ & & & 1. $40 \mathrm{E}+14$ & 0.0 & 9700.0 \\
\hline 81. & $\mathrm{SH}+\mathrm{O}=\mathrm{H}+\mathrm{SO}$ & & & 1.00E+14 & 0.0 & 0.0 \\
\hline 82 . & $\mathrm{SH}+\mathrm{OH}=\mathrm{S}+\mathrm{H} 2 \mathrm{O}$ & & & $1.00 \mathrm{E}+13$ & 0.0 & 0.0 \\
\hline 83 & $\mathrm{SH}+\mathrm{HO} 2=\mathrm{HSO}+\mathrm{OH}$ & & & 1.00E+12 & 0.0 & 0.0 \\
\hline 84. & $\mathrm{SH}+\mathrm{O} 2=\mathrm{HSO}+\mathrm{O}$ & & & 1.90E+13 & 0.0 & 9000.0 \\
\hline 85 & $\mathrm{~S}+\mathrm{OH}=\mathrm{H}+\mathrm{SO}$ & & & $4.00 \mathrm{E}+13$ & 0.0 & 0.0 \\
\hline 86. & $\mathrm{~S}+\mathrm{O} 2=\mathrm{SO}+\mathrm{O}$ & & & $5.20 E+06$ & 1.8 & -600.0 \\
\hline 87 & $2 \mathrm{SH}=\mathrm{S} 2+\mathrm{H} 2$ & & & 1.00E+12 & 0.0 & 0.0 \\
\hline 88 & $\mathrm{SH}+\mathrm{S}=\mathrm{S} 2+\mathrm{H}$ & & & $1.00 \mathrm{E}+13$ & 0.0 & 0.0 \\
\hline 89 & $\mathrm{~S} 2+\mathrm{M}=2 \mathrm{~S}+\mathrm{M}$ & & & $4.80 E+13$ & 0.0 & 38800.0 \\
\hline 90 & $\mathrm{~S} 2+\mathrm{H}+\mathrm{M}=\mathrm{HS} 2+\mathrm{M}$ & & & $1.00 \mathrm{E}+16$ & 0.0 & 0.0 \\
\hline & N2 & Enhanced by & 1. $500 \mathrm{E}+00$ & & & \\
\hline & $\mathrm{SO} 2$ & Enhanced by & 1.000E+01 & & & \\
\hline & $\mathrm{H} 2 \mathrm{O}$ & Enhanced by & $1.000 \mathrm{E}+01$ & & & \\
\hline 91. & $\mathrm{~S} 2+\mathrm{O}=\mathrm{SO}+\mathrm{S}$ & & & $1.00 \mathrm{E}+13$ & 0.0 & 0.0 \\
\hline 92. & $\mathrm{HS} 2+\mathrm{H}=\mathrm{S} 2+\mathrm{H} 2$ & & & 1.20E+07 & 2.1 & 352.4 \\
\hline 93. & $\mathrm{HS} 2+\mathrm{O}=\mathrm{S} 2+\mathrm{OH}$ & & & $7.50 \mathrm{E}+07$ & 1.8 & 1460.0 \\
\hline 94. & $\mathrm{HS} 2+\mathrm{OH}=\mathrm{S} 2+\mathrm{H} 2 \mathrm{O}$ & & & $2.70 \mathrm{E}+12$ & 0.0 & 0.0 \\
\hline 95. & $\mathrm{HS} 2+\mathrm{S}=\mathrm{S} 2+\mathrm{SH}$ & & & $8 \cdot 30 \mathrm{E}+13$ & 0.0 & 3700.0 \\
\hline & $\mathrm{SO}+\mathrm{O}(+\mathrm{M})=\mathrm{SO} 2(+\mathrm{M})$ & & & $3.20 \mathrm{E}+13$ & 0.0 & 0.0 \\
\hline & $\mathrm{N} 2$ & Enhanced by & 1. $500 \mathrm{E}+00$ & & & \\
\hline & $\mathrm{SO} 2$ & Enhanced by & $1.000 \mathrm{E}+01$ & & & \\
\hline & $\mathrm{H} 2 \mathrm{O}$ & Enhanced by & $1.000 \mathrm{E}+01$ & & & \\
\hline & Low pressure limi & it: $\quad 0.12000 \mathrm{E}+22$ & $2-0.15400$ & $\mathrm{E}+01$ & $000 E+00$ & \\
\hline & TROE centering: & $0.55000 \mathrm{E}+00$ & $0 \quad 0.10000$ & $E-29$ & $000 E+31$ & \\
\hline 97. & $\mathrm{SO} 2+\mathrm{CO}=\mathrm{SO}+\mathrm{CO} 2$ & & & $2.70 \mathrm{E}+12$ & 0.0 & 24300.0 \\
\hline 98. & $\mathrm{SO}+\mathrm{M}=\mathrm{S}+\mathrm{O}+\mathrm{M}$ & & & 4.00E+14 & 0.0 & 54000.0 \\
\hline & N2 & Enhanced by & $1.500 \mathrm{E}+00$ & & & \\
\hline & $\mathrm{SO} 2$ & Enhanced by & 1.000E+01 & & & \\
\hline & $\mathrm{H} 2 \mathrm{O}$ & Enhanced by & $1.000 \mathrm{E}+01$ & & & \\
\hline 99. & $\mathrm{SO}+\mathrm{H}+\mathrm{M}=\mathrm{HSO}+\mathrm{M}$ & & & $5.00 \mathrm{E}+15$ & 0.0 & 0.0 \\
\hline & N2 & Enhanced by & $1.500 \mathrm{E}+00$ & & & \\
\hline & $\mathrm{SO} 2$ & Enhanced by & $1.000 \mathrm{E}+01$ & & & \\
\hline & $\mathrm{H} 2 \mathrm{O}$ & Enhanced by & $1.000 \mathrm{E}+01$ & & & \\
\hline & $\mathrm{SO}+\mathrm{OH}=\mathrm{SO} 2+\mathrm{H}$ & & & $1.08 \mathrm{E}+17$ & -1.4 & 0.0 \\
\hline & $\mathrm{SO}+\mathrm{O} 2=\mathrm{SO} 2+\mathrm{O}$ & & & $7.60 \mathrm{E}+03$ & 2.4 & 1500.0 \\
\hline 0 & $2 \mathrm{SO}=\mathrm{SO} 2+\mathrm{S}$ & & & $2.00 \mathrm{E}+12$ & 0.0 & 2000.0 \\
\hline
\end{tabular}

Figure A3. Gas phase reaction mechanism. 


\begin{tabular}{|c|c|c|c|c|c|}
\hline 103. & $\mathrm{HSO}+\mathrm{H}=\mathrm{SH}$ & & $4.90 \mathrm{E}+19$ & -1.9 & 785.0 \\
\hline 104. & $\mathrm{HSO}+\mathrm{H}=\mathrm{S}+\mathrm{H} 2 \mathrm{O}$ & & $1.60 \mathrm{E}+09$ & 1.4 & -170.0 \\
\hline 105. & $\mathrm{HSO}+\mathrm{H}=\mathrm{H} 2 \mathrm{~S}+\mathrm{O}$ & & $1.10 \mathrm{E}+06$ & 1.0 & 5230.0 \\
\hline 106. & $\mathrm{HSO}+\mathrm{H}=\mathrm{SO}+\mathrm{H} 2$ & & $1.00 E+13$ & 0.0 & 0.0 \\
\hline 107. & $\mathrm{HSO}+\mathrm{O}=\mathrm{SO} 2+\mathrm{H}$ & & $4.50 \mathrm{E}+14$ & -0.4 & 0.0 \\
\hline 108. & $\mathrm{HSO}+\mathrm{O}=\mathrm{OH}+\mathrm{SO}$ & & $1.40 \mathrm{E}+13$ & 0.1 & 150.0 \\
\hline 109. & $\mathrm{HSO}+\mathrm{OH}=\mathrm{SO}+\mathrm{H} 2 \mathrm{O}$ & & $1.70 \mathrm{E}+09$ & 1.0 & 235.0 \\
\hline 110. & $\mathrm{HSO}+\mathrm{O} 2=\mathrm{SO} 2+\mathrm{OH}$ & & $1.00 \mathrm{E}+12$ & 0.0 & 5000.0 \\
\hline 111. & $\mathrm{~S}+\mathrm{CH} 4=\mathrm{SH}+\mathrm{CH} 3$ & & $6.00 \mathrm{E}+14$ & 0.0 & 12078.4 \\
\hline 112. & $\mathrm{H} 2 \mathrm{~S}+\mathrm{CH} 3=\mathrm{CH} 4+\mathrm{SH}$ & & $1.80 \mathrm{E}+11$ & 0.0 & 1177.5 \\
\hline 113. & $\mathrm{SH}+\mathrm{O}=\mathrm{S}+\mathrm{OH}$ & & $6.30 \mathrm{E}+11$ & 0.5 & 4030.6 \\
\hline 114. & $\mathrm{O}+\mathrm{COS}=\mathrm{CO}+\mathrm{SO}$ & & $4.70 \mathrm{E}+13$ & 0.0 & 5200.0 \\
\hline 115. & $\mathrm{COS}+\mathrm{M}=\mathrm{CO}+\mathrm{S}+\mathrm{M}$ & & $2.50 E+14$ & 0.0 & 61400.0 \\
\hline 116. & $\mathrm{O}+\mathrm{COS}=\mathrm{CO} 2+\mathrm{S}$ & & $2.00 E+13$ & 0.0 & 7385.0 \\
\hline 117. & $\mathrm{CO}+\mathrm{SH}=\mathrm{COS}+\mathrm{H}$ & & $2.50 \mathrm{E}+07$ & 0.0 & 15200.0 \\
\hline 118. & $\mathrm{OH}+\mathrm{COS}=\mathrm{CO} 2+\mathrm{SH}$ & & $4.60 \mathrm{E}+11$ & 0.0 & 16040.0 \\
\hline 119. & $\mathrm{O} 2+\mathrm{COS}=\mathrm{CO}+\mathrm{SO} 2$ & & $1.00 \mathrm{E}+12$ & 0.0 & 32000.0 \\
\hline 120. & $\mathrm{~S}+\mathrm{COS}=\mathrm{CO}+\mathrm{S} 2$ & & $4.00 \mathrm{E}+04$ & 2.6 & 2345.0 \\
\hline 121. & $\mathrm{SH}+\mathrm{O} 2=\mathrm{SO}+\mathrm{OH}$ & & $1.00 \mathrm{E}+12$ & 0.0 & 5032.5 \\
\hline 122. & $\mathrm{H}+\mathrm{CL}+\mathrm{M}=\mathrm{HCL}+\mathrm{M}$ & & $2.00 \mathrm{E}+23$ & -2.5 & 0.0 \\
\hline & $\mathrm{H} 2$ & Enhanced by & & & \\
\hline & CL2 & Enhanced by & & & \\
\hline & $\mathrm{N} 2$ & Enhanced by & & & \\
\hline 123. & $\mathrm{CL}+\mathrm{H} 2=\mathrm{HCL}+\mathrm{H}$ & & $9.50 \mathrm{E}+07$ & 1.7 & 3060.0 \\
\hline 124. & $\mathrm{HCL}+\mathrm{O}=\mathrm{CL}+\mathrm{OH}$ & & $5.90 E+05$ & 2.1 & 4024.0 \\
\hline 125. & $\mathrm{HCL}+\mathrm{OH}=\mathrm{CL}+\mathrm{H} 2 \mathrm{O}$ & & $4.10 \mathrm{E}+05$ & 2.1 & -1284.0 \\
\hline 126. & $\mathrm{CL}+\mathrm{HO} 2=\mathrm{HCL}+\mathrm{O} 2$ & & $7.50 \mathrm{E}+14$ & -0.6 & 0.0 \\
\hline 127. & $\mathrm{CL}+\mathrm{HO} 2=\mathrm{CLO}+\mathrm{OH}$ & & $3.80 E+13$ & 0.0 & 1200.0 \\
\hline 128. & $\mathrm{CL}+\mathrm{CL}+\mathrm{M}=\mathrm{CL} 2+\mathrm{M}$ & & $2.30 E+19$ & -1.5 & 0.0 \\
\hline & $\mathrm{H} 2$ & Enhanced by & & & \\
\hline & CL2 & Enhanced by & & & \\
\hline & $\mathrm{N} 2$ & Enhanced by & & & \\
\hline 129. & $\mathrm{CL} 2+\mathrm{H}=\mathrm{HCL}+\mathrm{CL}$ & & $8.60 \mathrm{E}+13$ & 0.0 & 1172.0 \\
\hline 130. & $\mathrm{CL} 2+\mathrm{O}=\mathrm{CL}+\mathrm{CLO}$ & & $4.50 \mathrm{E}+12$ & 0.0 & 3279.0 \\
\hline 131. & $\mathrm{CL} 2+\mathrm{OH}=\mathrm{HOCL}+\mathrm{CL}$ & & $2.20 \mathrm{E}+08$ & 1.4 & 1480.0 \\
\hline 132. & $\mathrm{CL}+\mathrm{OH}+\mathrm{M}=\mathrm{HOCL}+\mathrm{M}$ & & $1.20 \mathrm{E}+19$ & -1.4 & 0.0 \\
\hline 133. & $\mathrm{HOCL}=\mathrm{CLO}+\mathrm{H}$ & & $8.10 \mathrm{E}+14$ & -2.1 & 93690.0 \\
\hline 134. & $\mathrm{HOCL}+\mathrm{H}=\mathrm{CLO}+\mathrm{H} 2$ & & $4.40 \mathrm{E}-04$ & 4.9 & 425.0 \\
\hline 135. & $\mathrm{HOCL}+\mathrm{H}=\mathrm{HCL}+\mathrm{OH}$ & & $6.10 \mathrm{E}+07$ & 2.0 & 421.0 \\
\hline 136. & $\mathrm{HOCL}+\mathrm{O}=\mathrm{CLO}+\mathrm{OH}$ & & $3.30 \mathrm{E}+03$ & 2.9 & 1592.0 \\
\hline 137. & $\mathrm{HOCL}+\mathrm{OH}=\mathrm{CLO}+\mathrm{H} 2 \mathrm{O}$ & & 1. $30 \mathrm{E}+00$ & 3.6 & -2684.0 \\
\hline 138. & $\mathrm{HOCL}+\mathrm{CL}=\mathrm{HCL}+\mathrm{CLO}$ & & $3.60 \mathrm{E}-01$ & 4.1 & -337.0 \\
\hline 139. & $\mathrm{CLO}+\mathrm{H}=\mathrm{CL}+\mathrm{OH}$ & & $3.80 \mathrm{E}+13$ & 0.0 & 0.0 \\
\hline 140. & $\mathrm{CLO}+\mathrm{H}=\mathrm{HCL}+\mathrm{O}$ & & $8.40 \mathrm{E}+12$ & 0.0 & 0.0 \\
\hline 141. & $\mathrm{CLO}+\mathrm{O}=\mathrm{CL}+\mathrm{O} 2$ & & $1.50 \mathrm{E}+13$ & 0.0 & -219.0 \\
\hline 142. & $\mathrm{CLO}+\mathrm{OH}=\mathrm{HCL}+\mathrm{O} 2$ & & $3.50 \mathrm{E}+05$ & 1.7 & -3827.0 \\
\hline 143. & $\mathrm{CLO}+\mathrm{HO} 2=\mathrm{HOCL}+\mathrm{O} 2$ & & $7.80 E+03$ & 2.4 & 5110.0 \\
\hline 144. & $\mathrm{CLO}+\mathrm{CLO}=\mathrm{CL} 2+\mathrm{O} 2$ & & $6.60 \mathrm{E}+10$ & 0.7 & 3760.0 \\
\hline 145. & $\mathrm{CH} 2 \mathrm{O}+\mathrm{CL}=\mathrm{HCO}+\mathrm{HCL}$ & & $4.90 \mathrm{E}+13$ & 0.0 & 68.0 \\
\hline 146. & $\mathrm{CH} 2 \mathrm{O}+\mathrm{CLO}=\mathrm{HCO}+\mathrm{HOCI}$ & & $7.20 \mathrm{E}+10$ & 0.8 & 5961.0 \\
\hline 147. & $\mathrm{HCO}+\mathrm{CL}=\mathrm{CO}+\mathrm{HCL}$ & & $1.00 \mathrm{E}+14$ & 0.0 & 0.0 \\
\hline 148. & $\mathrm{HCO}+\mathrm{CLO}=\mathrm{HOCL}+\mathrm{CO}$ & & $3.20 \mathrm{E}+13$ & 0.0 & 0.0 \\
\hline 149. & $\mathrm{CO}+\mathrm{CLO}=\mathrm{CO} 2+\mathrm{CL}$ & & $2.40 \mathrm{E}+05$ & 2.0 & 10500.0 \\
\hline 150. & $\mathrm{CL}+\mathrm{CO}+\mathrm{M}=\mathrm{CLCO}+\mathrm{M}$ & & $1.20 \mathrm{E}+24$ & -3.8 & 0.0 \\
\hline 151. & $\mathrm{CLCO}+\mathrm{H}=\mathrm{CO}+\mathrm{HCL}$ & & $1.00 \mathrm{E}+14$ & 0.0 & 0.0 \\
\hline 152. & $\mathrm{CLCO}+\mathrm{O}=\mathrm{CO}+\mathrm{CLO}$ & & $1.00 \mathrm{E}+14$ & 0.0 & 0.0 \\
\hline 153. & $\mathrm{CLCO}+\mathrm{O}=\mathrm{CO} 2+\mathrm{CL}$ & & $1.00 \mathrm{E}+13$ & 0.0 & 0.0 \\
\hline 154. & $\mathrm{CLCO}+\mathrm{OH}=\mathrm{CO}+\mathrm{HOCL}$ & & $3.30 \mathrm{E}+12$ & 0.0 & 0.0 \\
\hline 155 & $\mathrm{CLCO}+\mathrm{O} 2=\mathrm{CO} 2+\mathrm{CLO}$ & & $7.90 \mathrm{E}+10$ & 0.0 & 3300.0 \\
\hline 156 & $\mathrm{CLCO}+\mathrm{CL}=\mathrm{CO}+\mathrm{CL} 2$ & & $6.60 E+13$ & 0.0 & 1400.0 \\
\hline
\end{tabular}

Figure A4. Gas phase reaction mechanism.

\section{References}

1. British Petroleum. Statistical Review of World Energy 2019; British Petroleum: London, UK, 2019.

2. Organization of the Petroleum Exporting Countries (OPEC). World Oil Outlook 2018; OPEC: Vienna, Austria, 2018.

3. Uusitalo, M.A.; Vuoristo, P.M.J.; Mäntylä, T.A. High temperature corrosion of coatings and boiler steels in oxidizing chlorine-containing atmosphere. Mater. Sci. Eng. A 2003, 346, 168-177. [CrossRef]

4. Young, D.J. High Temperature Oxidation and Corrosion of Metals; Elsevier: Amsterdam, The Netherlands, 2008.

5. Jones, J.M.; Patterson, P.M.; Pourkashanian, M.; Williams, A.; Arenillas, A.; Rubiera, F.; Pis, J.J. Modelling nox formation in coal particle combustion at high temperature: An investigation of the devolatilisation kinetic factors. Fuel 1999, 78, 1171-1179. [CrossRef] 
6. Backreedy, R.I.; Habib, R.; Jones, J.M.; Pourkashanian, M.; Williams, A. An extended coal combustion model. Fuel 1999, 78, 1745-1754. [CrossRef]

7. Authier, O.; Thunin, E.; Plion, P.; Schönnenbeck, C.; Leyssens, G.; Brilhac, J.F.; Porcheron, L. Kinetic study of pulverized coal devolatilization for boiler cfd modeling. Fuel 2014, 122, 254-260. [CrossRef]

8. Zhou, C.R.; Sendt, K.; Haynes, B.S. Experimental and kinetic modelling study of h2s oxidation. Proc. Combust. Inst. 2013, 34, 625-632. [CrossRef]

9. Vascellari, M.; Arora, R.; Pollack, M.; Hasse, C. Simulation of entrained flow gasification with advanced coal conversion submodels. part 1: Pyrolysis. Fuel 2013, 113, 654-669. [CrossRef]

10. Han, X.; Wei, X.; Schnell, U.; Hein, K.R. Detailed modeling of hybrid reburn/sncr processes for nox reduction in coal-fired furnaces. Combust. Flame 2003, 132, 374-386. [CrossRef]

11. Wei, X.; Guo, X.; Li, S.; Han, X.; Schnell, U.; Scheffknecht, G.; Risio, B. Detailed modeling of nox and sox formation in co-combustion of coal and biomass with reduced kinetics. Energy Fuels 2012, 26, 3117-3124. [CrossRef]

12. Lee, B.H.; Song, J.H.; Kim, R.G.; Kim, S.G.; Kim, Y.G.; Chang, Y.J.; Jeon, C.H. Simulation of the influence of the coal volatile matter content on fuel no emissions in a drop tube furnace. Energy Fuels 2010, 24. [CrossRef]

13. Belošević, S.; Tomanović, I.; Beljanski, V.; Tucaković, D.; Živanović, T. Numerical prediction of processes for clean and efficient combustion of pulverized coal in power plants. Appl. Therm. Eng. 2015, 74, 102-110. [CrossRef]

14. Constenla, I.; Ferrín, J.L.; Saavedra, L. Numerical study of a 350 mwe tangentially fired pulverized coal furnace of the as pontes power plant. Fuel Process. Technol. 2013, 116, 189-200. [CrossRef]

15. Müller, M.; Schnell, U.; Scheffknecht, G. Modelling the fate of sulphur during pulverized coal combustion under conventional and oxy-fuel conditions. Energy Procedia 2013, 37, 1377-1388. [CrossRef]

16. Maffei, T.; Sommariva, S.; Ranzi, E.; Faravelli, T. A predictive kinetic model of sulfur release from coal. Fuel 2012, 91, 213-223. [CrossRef]

17. Modlinski, N.; Hardy, T. Development of high-temperature corrosion risk monitoring system in pulverized coal boilers based on reducing conditions identification and cfd simulations. Appl. Energy 2017, 204, 1124-1137. [CrossRef]

18. Li, M.J.; Tang, S.Z.; Wang, F.L.; Zhao, Q.X.; Tao, W.Q. Gas-side fouling, erosion and corrosion of heat exchangers for middle/low temperature waste heat utilization: A review on simulation and experiment. Appl. Therm. Eng. 2017, 126, 737-761. [CrossRef]

19. Wang, Y.; Tang, G. Prediction of sulfuric acid dew point temperature on heat transfer fin surface. Appl. Therm. Eng. 2016, 98, 492-501. [CrossRef]

20. Hughes, K.J.; Tomlin, A.S.; Dupont, V.A.; Pourkashanian, M. Experimental and modelling study of sulfur and nitrogen doped premixed mehtane flames at low pressure. Faraday Discuss 2001, 119, 337-352. [CrossRef]

21. Ströhle, J.; Chen, X.; Zorbach, I.; Epple, B. Validation of a detailed reaction mechanism for sulfur species in coal combustion. Combust. Sci. Technol. 2014, 186, 540-551. [CrossRef]

22. von Bohnstein, M.; Langen, J.; Frigge, L.; Stroh, A.; Strohle, J.; Epple, B. Comparison of cfd simulations with measurements of gaseous sulfur species concentrations in a pulverized coal fired 1 mwth furnace. Energy Fuels 2016, 30, 9836-9849. [CrossRef]

23. Oh, M.S.; Burnham, A.K.; Crawford, R.W. Evolution of sulfur gases during coal pyrolysis. Prepr. Am. Chem. Soc. Div. Fuel Chem. 1988, 33, 274-282.

24. Shao, D.; Hutchinson, E.J.; Heidbrink, J.; Pan, W.P.; Chou, C.L. Behavior of sulfur during coal pyrolysis. J. Anal. Appl. Pyrolysis 1994, 30, 91-100. [CrossRef]

25. Bozic, O. Numerische Simulation der Mineralumwandlung in Kohlestaubfeuerungen. Ph.D. Thesis, Fakultät für Maschinenbau und Elektrotechnik, Braunschweig, Germany, 2001.

26. Strelow, M. Mineralumwandlung in Feuerungen. Ph.D. Thesis, Fakultät für Maschinenbau, Braunschweig, Germany 2012.

27. Garcia-Labiano, F.; Hampartsoumian, E.; Williams, A. Determination of sulfur release and its kinetics in rapid pyrolysis of coal. Fuel 1995, 74, 1072-1079. [CrossRef]

28. Chen, H.K.; Li, B.Q.; Yang, J.I.; Zhang, B.J. Transformation of sulfur during pyrolysis and hydropyrolysis of coal. Fuel 1998, 77, 487-493. [CrossRef]

29. Tomeczek, J.; Palugniok, H. Kinetics of mineral matter transformation during coal combustion. Fuel 2002, 81, 1251-1258. [CrossRef] 
30. Srinivasachar, S.; Helble, J.J.; Boni, A.A. Ash deposition mineral behavior during coal combustion 1. pyrite transformations. Prog. Energy Combust. Sci. 1990, 16, 281-292. [CrossRef]

31. Yan, X.; Ma, L.; Zhu, B.; Zheng, D.; Lian, Y. Reaction mechanism process analysis with phosphogypsum decomposition in multiatmosphere control. Ind. Eng. Chem. Res. 2014, 53, 19453-19459. [CrossRef]

32. Huang, J.J.; Zhao, J.T.; Chen, F.Y.; Zhang, Y.Q.; Wang, Y. Investigation of calcium sulfide regeneration with steam. J. China Univ. Min. Technol. 2005, 15, 288-292.

33. Magda, S.I. Modelling of Transformation and Deposition of Alkaline Compounds under Combustion Conditions. Ph.D. Thesis, Technische Universität, Braunschweig, Germany, 2012.

34. Akbar, S. Numerical Simulation of Deposit Formation in Coal-Fired Utility Boilers with Biomass Co-Combustion. Ph.D. Thesis, Universität Stuttgart, Stuttgart, Germany, 2011.

35. Steffin, C. Freisetzung und Einbindung von Alkalien bei der Verbrennung und Vergasung von Kohle unter Druck. Ph.D. Thesis, Universität-Gesamthochschule, Essen, Germany, 1998.

36. Tanaka, H. Thermal analysis and kinetics of solid state reactions. Thermochim. Acta 1995, 267, $29-44$. [CrossRef]

37. Khawam, A.; Flanagan, D.R. Solid-state kinetic models: Basics and mathematical fundamentals. J. Phys. Chem. B 2006, 110, 17315-17328. [CrossRef]

38. Magda, A.; Magda, S.I.; Strelow, M.; Muller, H.; Leithner, R. Cfd modelling of ash deposits in coal fired power plants. In Proceedings of the International Conference on Heat Exchanger Fouling and Cleaning, Crete Island, Greece , 5-10 June 2011; p. 301.

39. Frigge, L.; Elserafi, G.; Strohle, J.; Epple, B. Sulfur and chlorine gas species formation during coal pyrolysis in nitrogen and carbon dioxide atmosphere. Energy Fuels 2016, 30, 7713-7720. [CrossRef]

40. Sankaran, R.; Hawkes, E.R.; Chen, J.H.; Lu, T.; Law, C.K. Structure of a spatially developing turbulent lean methane-air bunsen flame. Proc. Combust. Inst. 2007, 31, 1291-1298. [CrossRef]

41. Pelucchi, M.; Frassoldati, A.; Faravelli, T.; Ruscic, B.; Glarborg, P. High-temperature chemistry of hcl and $\mathrm{cl} 2$. Combust. Flame 2015, 162, 2693-2704. [CrossRef]

42. Magnussen, B. On the structure of turbulence and a generalized eddy dissipation concept for chemical reaction in turbulent flow. In Proceedings of the Nineteenth AIAA Meeting, St. Louis, MO, USA, 12-15 January 1981.

43. Epple, B.; Fivel, W.; Krohmer, B.; Richards, G.; Benim, A.C. Assesment of two-phase flow models for the simulation of pulverized coal combustion. Int. J. Energy Clean Environ. 2005, 6, 267-287. [CrossRef]

44. Stroh, A.; Alobaid, F.; Busch, J.P.; Ströhle, J.; Epple, B. 3-d numerical simulation for co-firing of torrefied biomass in a pulverized-fired 1 mwth combustion chamber. Energy 2015, 85, 105-116. [CrossRef]

45. Benim, A.C.; Epple, B.; Krohmer, B. Modelling of pulverised coal combustion by a eulerian-eulerian two-phase flow formulation. Prog. Comput. Fluid Dyn. Int. J. 2005, 5, 345-361. [CrossRef]

46. Frigge, L. Untersuchung der Freisetzung von Schwefel- und Chlorverbindungen Während der Oxyfuel-Verbrennung von Kohle. Ph.D. Thesis, Technische Universität Darmstadt, Darmstadt, Germany, 2018. 